\title{
Visible-Light-Controlled Ruthenium-Catalyzed Olefin Metathesis
}

\author{
Cédric Theunissen, Melissa A. Ashley and Tomislav Rovis* \\ Department of Chemistry, Columbia University, 3000 Broadway, New York, NY, 10027.
}

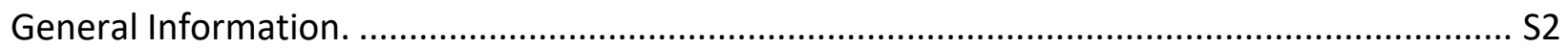

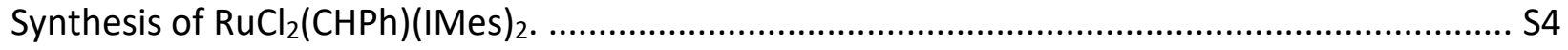

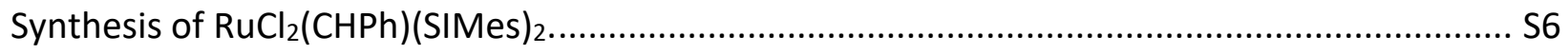

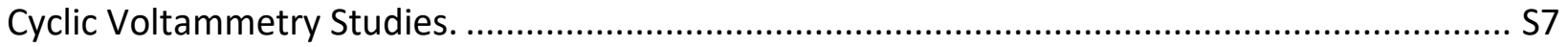

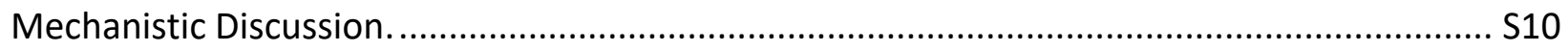

Extended Optimization Studies:

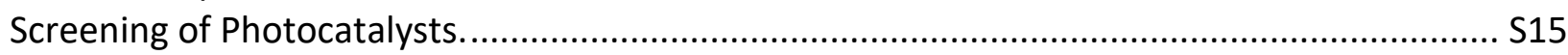

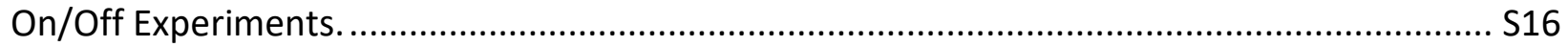

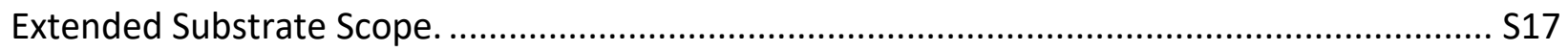

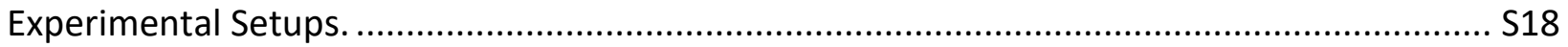

Experimental Procedures and Charachetization Data:

Metathesis for the Synthesis of Small Molecules................................................................. S22

Experimental Procedure and Characterization Data:

Ring Opening Metathesis Polymerization. .................................................................. S29

Experimental Procedure and Results:

Polymer Patterning using Masks. .................................................................................. S31

Experimental Procedure and Results:

Polymer Patterning using Blue Laser. .......................................................................... S34

Experimental Procedure and Results:

Photolithographic Applications on Silicon Wafers. ........................................................... S35

${ }^{1} \mathrm{H}$ and ${ }^{13} \mathrm{C}$ NMR Spectra:

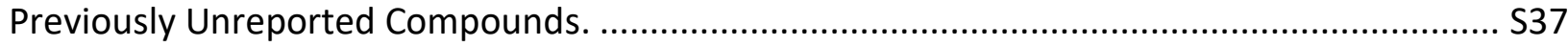




\section{General Information.}

All reactions were carried out in oven-dried glassware under an argon or nitrogen atmosphere employing standard techniques in handling air-sensitive materials.

All solvents were reagent grade. Dichloromethane (anhydrous, $\geq 99.8 \%$ ), hexane (anhydrous, 95\%), pyridine (anhydrous, 99.8\%) and toluene (anhydrous, 99.8\%) were purchased from Sigma-Aldrich and used as supplied. Benzene (anhydrous, 99.8\%) was purchased from Merck and used as supplied. Grubbs $1^{\text {st }}$ and $2^{\text {nd }}$ generation catalysts and SIMes were purchased from Sigma Aldrich and used as supplied. IMes was purchased from $\mathrm{TCl}$ Chemicals and used as supplied. All photocatalysts used were either synthesized by known methods or bought from commercial sources. 2,4,6-Triphenylpyrylium tetrafluoroborate in particular was purchased from Sigma Aldrich and used as supplied. Trichloro(5-norbornen-2-yl)silane was synthesized based on a reported procedure. ${ }^{1}$ All other reagents were used as supplied.

All photochemical reactions were performed in 1-dram vials fitted with Teflon caps under irradiation with two blue PR160-440nm Kessil 40W LED lamps. Reactions were magnetically stirred and monitored by thin layer chromatography using SiliCycle ${ }^{\circledR} 250 \mu \mathrm{m} 60 \AA$ plates. Flash chromatography was performed with silica gel $60 \AA$ (particle size $40-63 \mu \mathrm{m}$ ) supplied by SiliCycle ${ }^{\circledR}$. Yields refer to chromatographically and spectroscopically pure compounds unless otherwise stated.

All polymer patterning experiments were performed in BRAND ${ }^{\circledR}$ petri dishes (glass, $40 \mathrm{~mm}$ x $12 \mathrm{~mm}$ or $80 \mathrm{~mm}$ x $15 \mathrm{~mm}$ ) purchased from Sigma Aldrich. A UKing ZQ-J33 $200 \mathrm{~mW}$ 532nm \& $450 \mathrm{~nm}$ double light 5 in 1 USB laser pointer was purchased from www.laserpointerpro.com. Silicon wafers (4", $2850 \AA$ Axide layer, resistivity .001-.005 ohm-cm, p-type, orientation <100>) were purchased from NOVA Electronic Materials (Item \#HS39626-OX). Masks were drawn in CAD software and printed by CAD/ART Services, Inc. (Brandon, OR).

Proton NMR spectra were recorded using an internal deuterium lock at ambient temperature on a Bruker $500 \mathrm{MHz}$ spectrometer. Internal reference of $\delta_{\mathrm{H}} 7.26$ was used for $\mathrm{CDCl}_{3}$. Data are presented as follows: chemical shift (in ppm on the $\delta$ scale relative to $\delta$ TMS $=0$ ), multiplicity $(\mathrm{s}=$ singlet, $\mathrm{d}=$ doublet, $\mathrm{t}=$ triplet, $\mathrm{q}=$ quartet, $\mathrm{m}=$ multiplet, $\mathrm{br} .=$ broad, app. $=$ apparent), coupling constant $(\mathrm{J} / \mathrm{Hz})$ and integration. Resonances that are either partially or fully obscured are denoted obscured (obs.). Carbon-13 NMR spectra were recorded at $125 \mathrm{MHz}$ using 
$\mathrm{CDCl}_{3}\left(\delta_{\mathrm{c}} 77.16\right)$ as internal reference. Fluorine-19 NMR spectra were recorder at $470 \mathrm{MHz}$ using $\mathrm{CF}_{3} \mathrm{CH}_{2} \mathrm{OH}\left(\delta_{\mathrm{F}}-77.59\right)$ as external reference.

High-resolution mass spectra were obtained on a Waters XEVO G2XSQToF mass spectrometer. Infrared spectra were recorded on a Perkin Elmer Spectrum Two FT-IR Spectrometer. GPC analysis were performed on an Agilent 1260 Infinity GPC using 2x300 mm Agilent PLGel Mixed-D columns and G1362A RI or G1365D multiwavelength detectors, calibrated against polystyrene standards.

All cyclic voltammetry studies were performed on a $\mathrm{CH}$ instruments Model $1232 \mathrm{~B}$ potentiostat using an EDAQ 1-mm disk glassy carbon working electrode in conjunction with an EDAQ $\mathrm{Ag} / \mathrm{AgCl}$ reference electrode and a platinum wire from VWR as counter electrode. All experiments were performed in anhydrous dichloromethane $\left(\mathrm{RuCl}_{2}(\mathrm{CHPh})(\mathrm{IMes})_{2}\right.$ and $\mathrm{RuCl}_{2}(\mathrm{CHPh})(\mathrm{SIMes})_{2}$ ) or tetrahydrofuran (free IMes and free SIMes) at $5 \mathrm{mM}$ using tetrabutylammonium hexafluorophosphate $(0.1 \mathrm{M})$ as electrolyte. The scan rate was set at 100 $\mathrm{mV} / \mathrm{s}$.

Plasma treatments were conducted using a PE-50 Compact Benchtop Plasma Cleaning System manufactured by Plasma Etch, Inc. Micrographs of the patterned silicon wafers were recorded on a Nikon Eclipse LV150N microscope. Step heights were measured by imaging $10 \mu \mathrm{m}$ sections $(0.5 \mathrm{~Hz}, 256$ samples/line) on a Bruker Dimension Icon AFM using a Scanasyst-Air probe in Scanasyst mode. 


\section{Synthesis of $\mathrm{RuCl}_{2}(\mathrm{CHPh})(\mathrm{IMes})_{2}$}

\section{- Synthesis of $\mathrm{RuCl}_{2}(\mathrm{CHPh})\left(\mathrm{PCy}_{3}\right)(\mathrm{IMes})$}

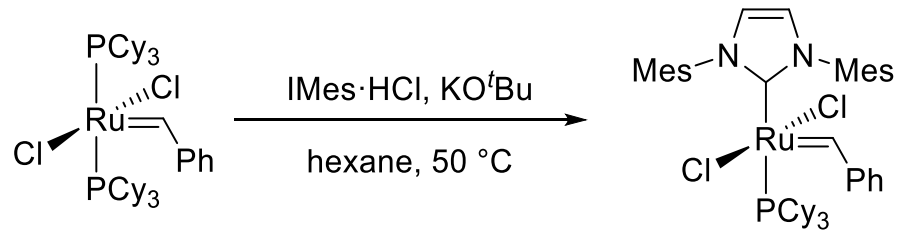

$\mathrm{RuCl}_{2}(\mathrm{CHPh})\left(\mathrm{PCy}_{3}\right)(\mathrm{IMes})$ was synthesized according to a procedure reported by Nolan. ${ }^{2}$ In a glovebox, a $50 \mathrm{~mL}$ round bottom flask was charged with Grubbs $1^{\text {st }}$ generation $(1.5 \mathrm{~g}, 1.82 \mathrm{mmol})$, IMes. $\mathrm{HCl}(933 \mathrm{mg}, 2.73 \mathrm{mmol}), \mathrm{KO}^{t} \mathrm{Bu}(450 \mathrm{mg}, 4.0 \mathrm{mmol})$ and anhydrous hexane (15 mL). The flask was sealed and removed from the glovebox before stirring at $50{ }^{\circ} \mathrm{C}$ for $5 \mathrm{~h}$. The resulting suspension was cooled to room temperature and filtered through a collection frit. The precipitate was finally washed with water and a minimal amount of hexane before being dried under vacuum to afford the desired $\mathrm{RuCl}_{2}(\mathrm{CHPh})\left(\mathrm{PCy}_{3}\right)$ (IMes) as a purple-brown solid (846 $\mathrm{mg}, 1.0 \mathrm{mmol}, 67 \%$ yield). The NMR data are in agreement with the literature values. ${ }^{3}$

\section{- Synthesis of $\mathrm{RuCl}_{2}(\mathrm{CHPh})(\mathrm{Py})_{2}$ (IMes)}

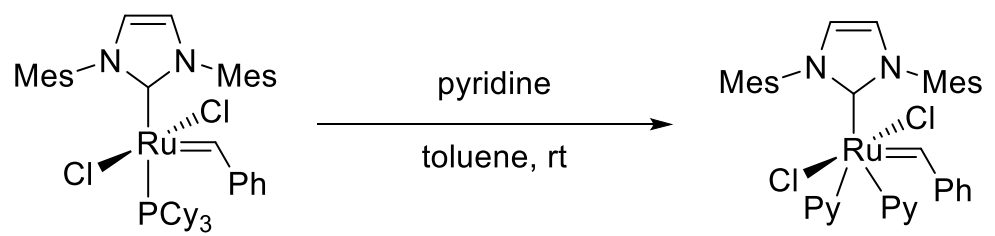

$\mathrm{RuCl}_{2}$ (CHPh)(Py) $)_{2}$ (IMes) was synthesized according to a procedure reported by Grubbs. ${ }^{4}$ In a glovebox, $\mathrm{RuCl}_{2}(\mathrm{CHPh})\left(\mathrm{PCy}_{3}\right)(\mathrm{IMes})(846 \mathrm{mg}, 1 \mathrm{mmol})$ was dissolved in anhydrous toluene (2.5 $\mathrm{mL}$ ) and pyridine $(6.5 \mathrm{~mL})$. The reaction mixture was stirred for $30 \mathrm{~min}$ at room temperature. During that time, a quick change in color from red to green could be observed. The reaction mixture was then concentrated under vacuum before pentane was added. The green residue was triturated in pentane and allowed to precipitate for 30 minutes at $-20{ }^{\circ} \mathrm{C}$. The precipitate was then filtered, washed with cold pentane $\left(-20^{\circ} \mathrm{C}\right)$ and finally dried under vacuum to afford $\mathrm{RuCl}_{2}(\mathrm{CHPh})(\mathrm{Py})_{2}$ (IMes) as a green solid $(689 \mathrm{mg}, 0.95 \mathrm{mmol}, 95 \%$ yield). The NMR data are in agreement with the literature values. ${ }^{5}$ 


\section{- Synthesis of $\mathrm{RuCl}_{2}(\mathrm{CHPh})(\mathrm{IMes})_{2}$}
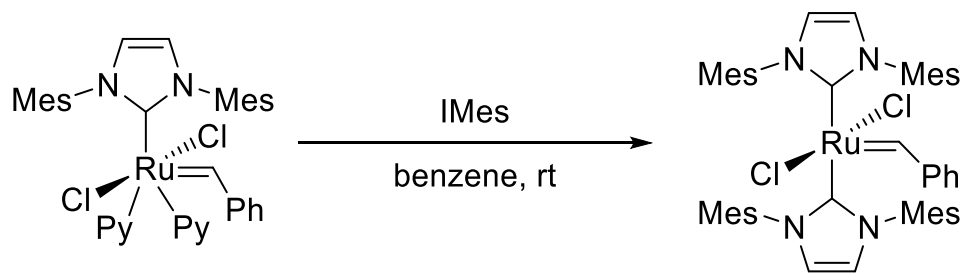

$\mathrm{RuCl}_{2}(\mathrm{CHPh})(\mathrm{IMes})_{2}$ was synthesized according to a procedure reported by Fogg. ${ }^{3 \mathrm{~b}}$ In a glovebox, a $100 \mathrm{~mL}$ round bottom flask was charged with $\mathrm{RuCl}_{2}(\mathrm{CHPh})(\mathrm{Py})_{2}(\mathrm{IMes})(944 \mathrm{mg}, 1.30 \mathrm{mmol})$, IMes (397 mg, $1.30 \mathrm{mmol}$ ) and anhydrous benzene $(50 \mathrm{~mL})$. The brown reaction mixture was stirred overnight at room temperature, filtered and concentrated under vacuum. The crude residue was then precipitated from cold pentane $\left(-20^{\circ} \mathrm{C}\right)$, filtered and washed with cold pentane $\left(-20^{\circ} \mathrm{C}\right)$. To improve its purity, the complex was extracted multiple times with boiling hexanes. The precipitate was therefore taken up in boiling hexanes and filtrated through a collection frit. This was repeated multiple times to recover most of the desired complex. The combined organic layers were finally concentrated under vacuum to afford the desired $\mathrm{RuCl}_{2}(\mathrm{CHPh})(\mathrm{IMes})_{2}$ as a brown solid (670 mg, $0.77 \mathrm{mmol}, 59 \%$ yield). The NMR data are in agreement with the literature values. ${ }^{4 b}$ 


\section{Synthesis of $\mathrm{RuCl}_{2}(\mathrm{CHPh})(\mathrm{SIMes})_{2}$}

\section{- Synthesis of $\mathrm{RuCl}_{2}(\mathrm{CHPh})(\mathrm{Py})_{2} \mathrm{SIMes}$}

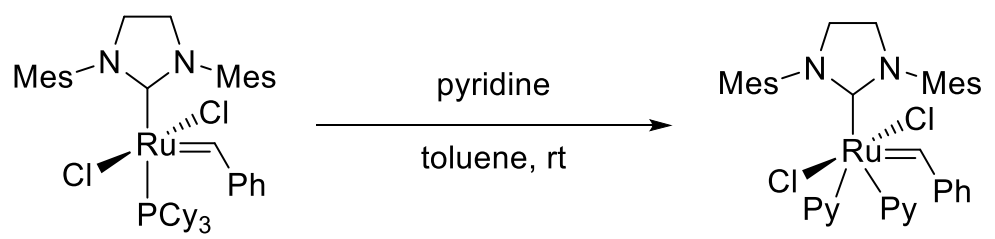

$\mathrm{RuCl}_{2}(\mathrm{CHPh})(\mathrm{Py})_{2}$ (SIMes) was synthesized according to a procedure reported by Grubbs. ${ }^{4 a}$ In a glovebox, Grubbs $2^{\text {nd }}$ generation $(250 \mathrm{mg}, 294 \mu \mathrm{mol}$ ) was dissolved in anhydrous toluene (750 $\mu \mathrm{L}$ ) and pyridine $(1.8 \mathrm{~mL})$. The reaction mixture was stirred for $30 \mathrm{~min}$ at room temperature. During that time, a quick change in color from red to green could be observed. The reaction mixture was then poured into cold pentane $\left(-20^{\circ} \mathrm{C}\right)$ inducing precipitation of a green solid. The solid was allowed to fully precipitate for 30 minutes at $-20{ }^{\circ} \mathrm{C}$ before being filtered, washed with cold pentane $\left(-20^{\circ} \mathrm{C}\right)$ and finally dried under vacuum to afford $\mathrm{RuCl}_{2}(\mathrm{CHPh})(\mathrm{Py})_{2}(\mathrm{SIMes})$ as a green solid (196 mg, $270 \mu \mathrm{mol}, 92 \%$ yield). The NMR data are in agreement with the literature values. ${ }^{3}$

- Synthesis of $\mathrm{RuCl}_{2}(\mathrm{CHPh})(\mathrm{SIMes})_{2}$

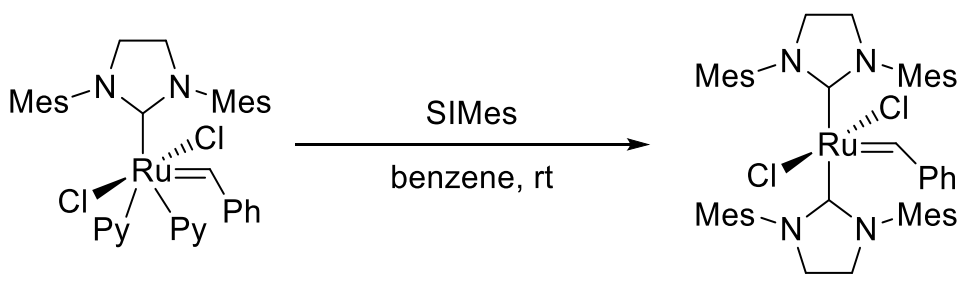

$\mathrm{RuCl}_{2}$ (CHPh)(SIMes) ${ }_{2}$ has already been reported by Grubbs. ${ }^{6}$ In a glovebox, a $25 \mathrm{~mL}$ round bottom flask was charged with $\mathrm{RuCl}_{2}(\mathrm{CHPh})(\mathrm{Py})_{2}(\mathrm{SIMes})(196 \mathrm{mg}, 270 \mu \mathrm{mol})$, SIMes (83 mg, $\left.270 \mathrm{mmol}\right)$ and benzene $(9 \mathrm{~mL})$. The brown reaction mixture was stirred at $45^{\circ} \mathrm{C}$ for $24 \mathrm{~h}$ before being cooled to room temperature and concentrated under vacuum. The crude residue was then precipitated from cold pentane $\left(-20^{\circ} \mathrm{C}\right)$, filtered and washed with cold pentane $\left(-20^{\circ} \mathrm{C}\right)$. To improve its purity, the complex was extracted multiple times with boiling hexanes. The precipitate was therefore taken up in boiling hexanes and filtrated through a collection frit. This was repeated multiple times to recover most of the desired complex. The combined organic layers were finally 
concentrated under vacuum to furnish the desired $\mathrm{RuCl}_{2}(\mathrm{CHPh})(\mathrm{SIMes})_{2}$ as a brown solid (150 $\mathrm{mg}, 171 \mu \mathrm{mol}, 63 \%$ yield). The NMR data are in agreement with the literature values. ${ }^{6}$

\section{Cyclic Voltammetry Studies}

Cyclic voltammetry studies were run using a glassy carbon electrode, a platinum wire counter electrode and an $\mathrm{Ag} / \mathrm{AgCl}$ reference electrode. For all studies, tetrabutylammonium hexafluorophosphate was used as the electrolyte in a solution of dichloromethane $\left(\mathrm{RuCl}_{2}(\mathrm{CHPh})(\mathrm{IMes})_{2}\right.$ and $\left.\mathrm{RuCl}_{2}(\mathrm{CHPh})(\mathrm{SIMes})_{2}\right)$ or tetrahydrofuran (free IMes and free SIMes) while nitrogen was bubbled through the solution prior to data collection. Sweeps were run negative (reductive) on first pass.

- $\mathrm{RuCl}_{2}(\mathrm{CHPh})(\mathrm{IMes})_{2}$ versus $\mathrm{Ag} / \mathrm{AgCl}$

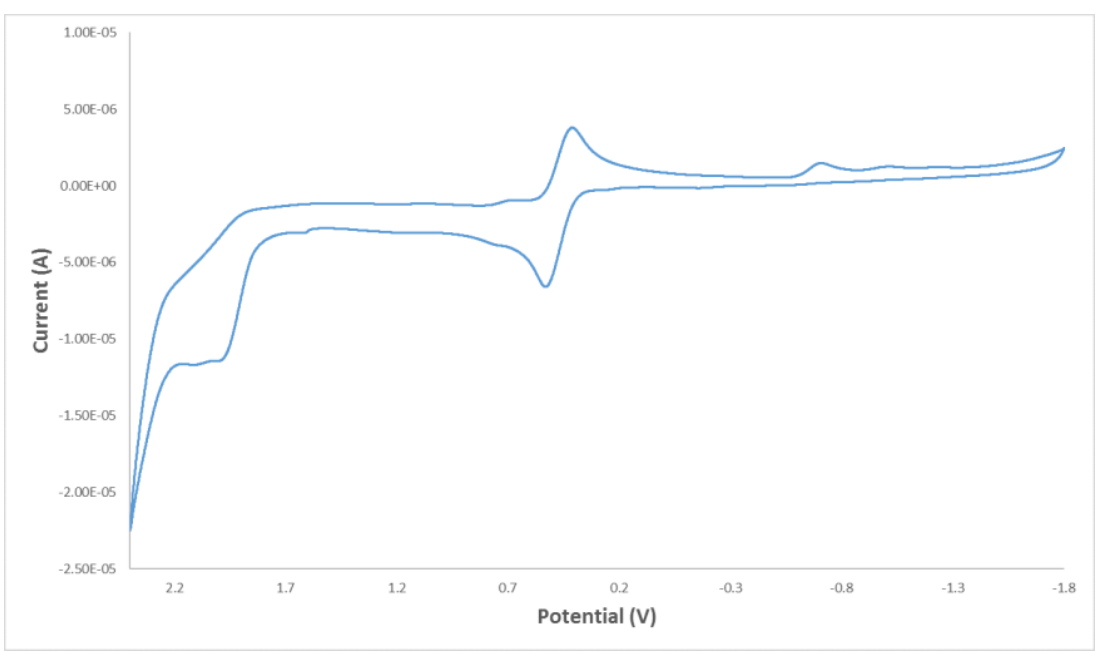


- $\mathrm{RuCl}_{2}(\mathrm{CHPh})(\mathrm{IMes})_{2}$ versus $\mathrm{Ag} / \mathrm{AgCl}$ (Differential Scan Rates - Cyclic Voltammetry)

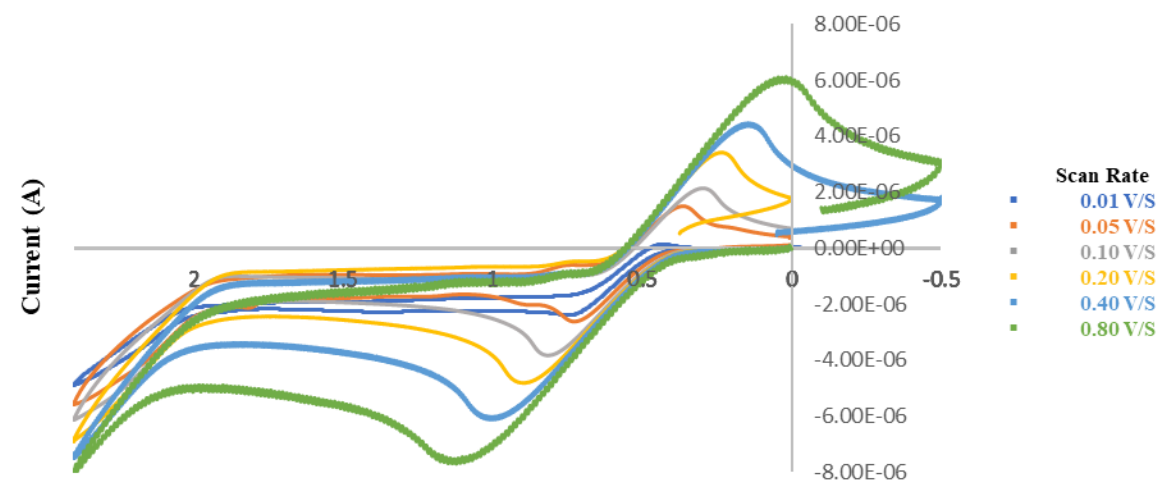

E vs. $\mathbf{A g} / \mathbf{A g C l}$

- $\mathrm{RuCl}_{2}(\mathrm{CHPh})(\mathrm{IMes})_{2}$ versus $\mathrm{Ag} / \mathrm{AgCl}$ (Differential Scan Rates - Linear Voltammetry)

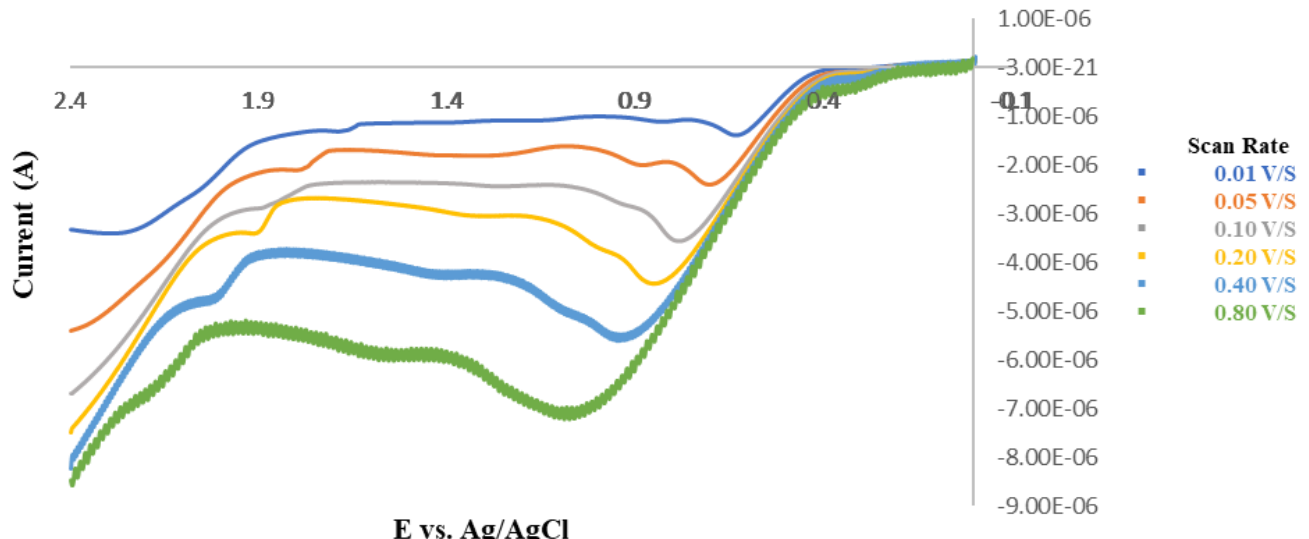

- IMes versus $\mathrm{Ag} / \mathrm{AgCl}$

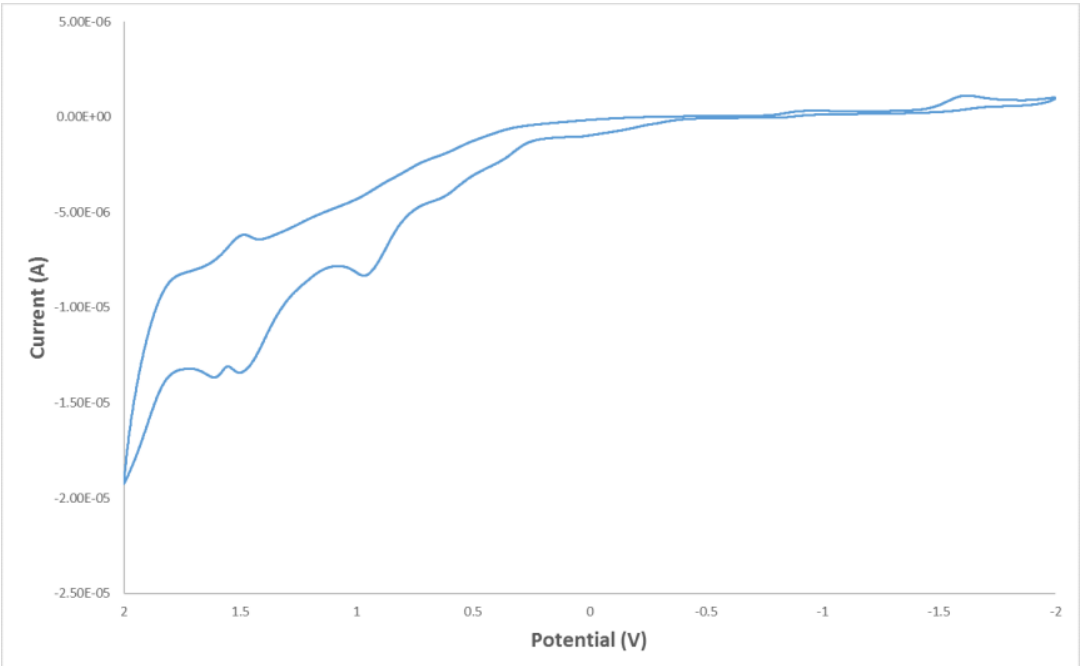


- $\mathrm{RuCl}_{2}(\mathrm{CHPh})(\mathrm{SIMes})_{2}$ versus $\mathrm{Ag} / \mathrm{AgCl}$

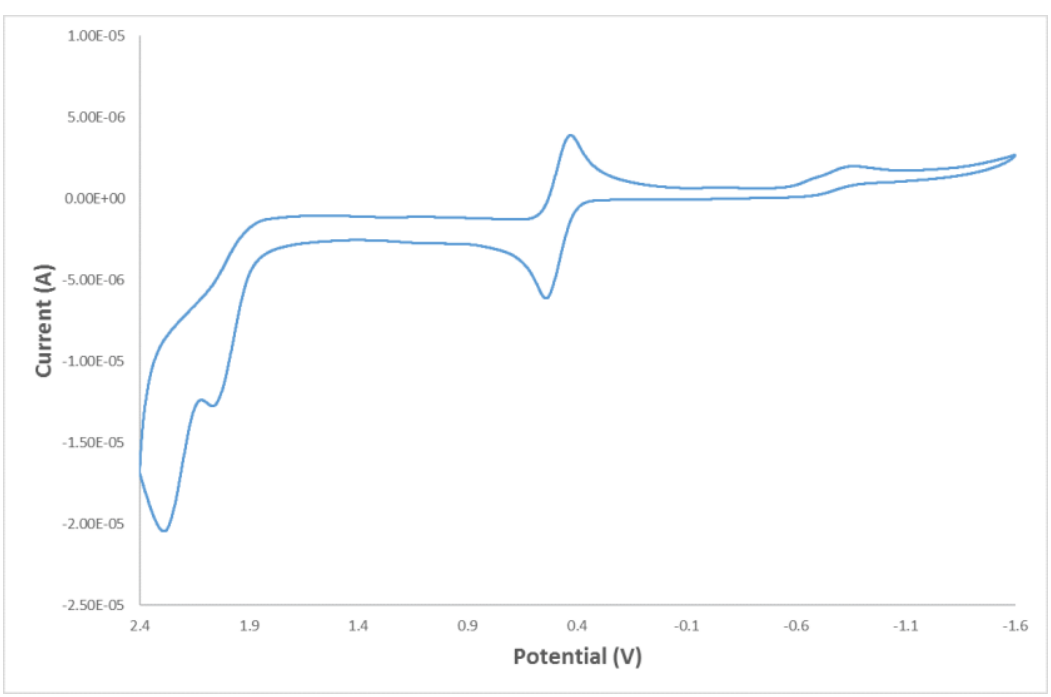

- $\quad$ SIMes versus $\mathrm{Ag} / \mathrm{AgCl}$

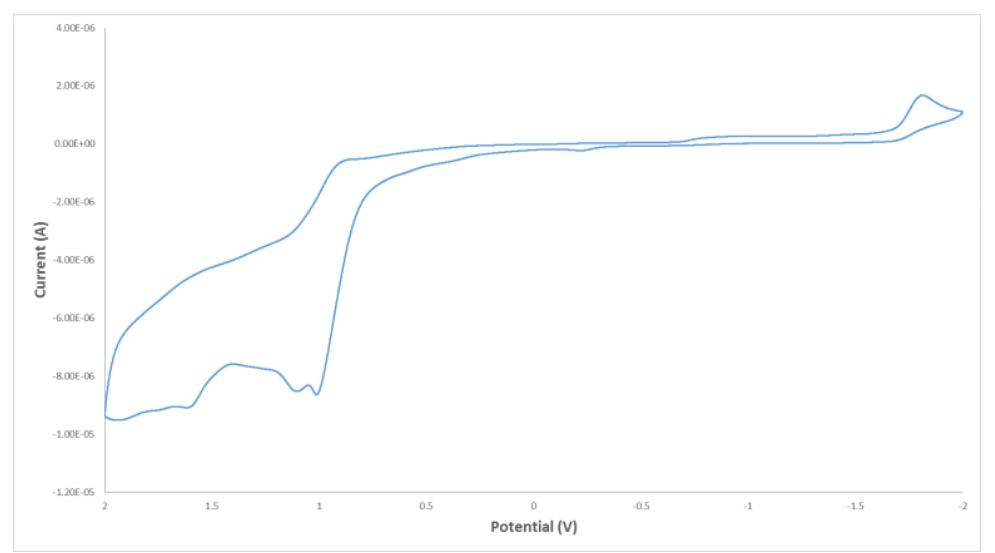

The cyclic voltammograms of ruthenium complexes $\mathrm{RuCl}_{2}(\mathrm{CHPh})(\mathrm{IMes})_{2}$ and $\mathrm{RuCl}_{2}(\mathrm{CHPh})(\mathrm{SIMes})_{2}$ both display a pseudo-reversible oxidation at $0.47 \mathrm{~V}(0.44 \mathrm{~V}$ vs SCE) and $0.49 \mathrm{~V}(0.43 \mathrm{~V}$ vs SCE), respectively, which are most probably related to the $\mathrm{Ru}(\mathrm{II}) / \mathrm{Ru}(\mathrm{III})$ couple. In addition, oxidation events at high potentials ( $>1.8 \mathrm{~V}$ ) are also observed on both cyclic voltammograms and are probably related to the oxidation of the carbene ligands. ${ }^{7}$ These oxidation events do not appear to be reversible. While the first oxidation process should be accessible by most Ru- and Ir-based photocatalysts, the events at high potentials are only accessible by much oxidizing photocatalysts such as acridinium and pyrylium derivatives. As described on the next page, only those highly oxidizing photocatalysts display some reactivity. 


\section{Mechanistic Discussion}

- Proposed mechanistic cycle

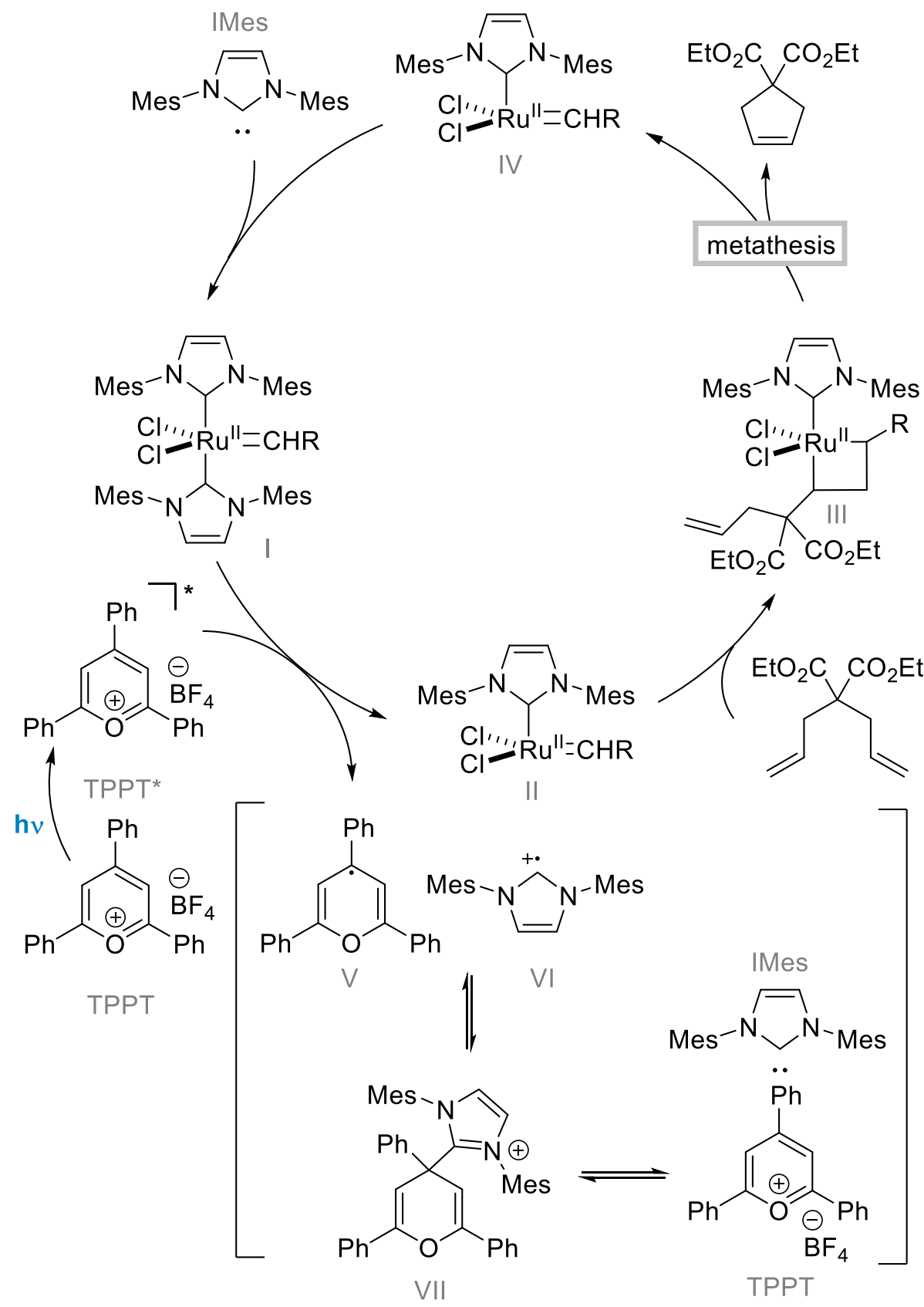

Evaluation of the optimized conditions and cyclic voltammetry support the above mechanisms. Given the high oxidation potential of the Ru catalyst and the necessity of a highly oxidizing photocatalyst we propose oxidation of the IMes ligand to liberate the active $\mathrm{Ru}(\mathrm{II})$ catalyst . Literature precedent of analogous redox couples with TPPT ${ }^{8}$ invoke formation of intermediate VII. 
Upon decomplexation, the ground state of TPPT is regenerated and the IMes can coordinate to IV. This complex formation between the reduced TPPT and oxidized IMes rationalizes the imperfect temporal control (0-3\% increase during dark periods). TPPT is the optimal catalyst because it is highly oxidizing and lewis acidic, which is accounted for in the proposed mechanism.

NMR experiments probe the nature of the Ru catalysts/TPPT before and after light. A 1:1 solution of the TPPT/Ruthenium catalyst was evaluated over a $36 \mathrm{~h}$ period with ${ }^{1} \mathrm{H}$ NMRs recorded every $10 \mathrm{~min}$. Upon irradiation with blue light $(5 \mathrm{~min})$ NMR experiments were performed. Diagnostic TPPT peaks have diminished/broadened in the aromatic range. Over the course of the kinetic study new peaks appear to form $\sim 4.8 \mathrm{ppm}$ and $\sim 8.0-8.1 \mathrm{ppm}$ as TPPT appears to disappear after light irradiation. We believe this could be due to complexation between the TPPT and the IMes ligand to form intermediate VII. Further mechanistic studies are currently underway that model the reaction conditions more closely.

Comparison of Ruthenium and TPPT catalysts prior and after blue light irradiation.

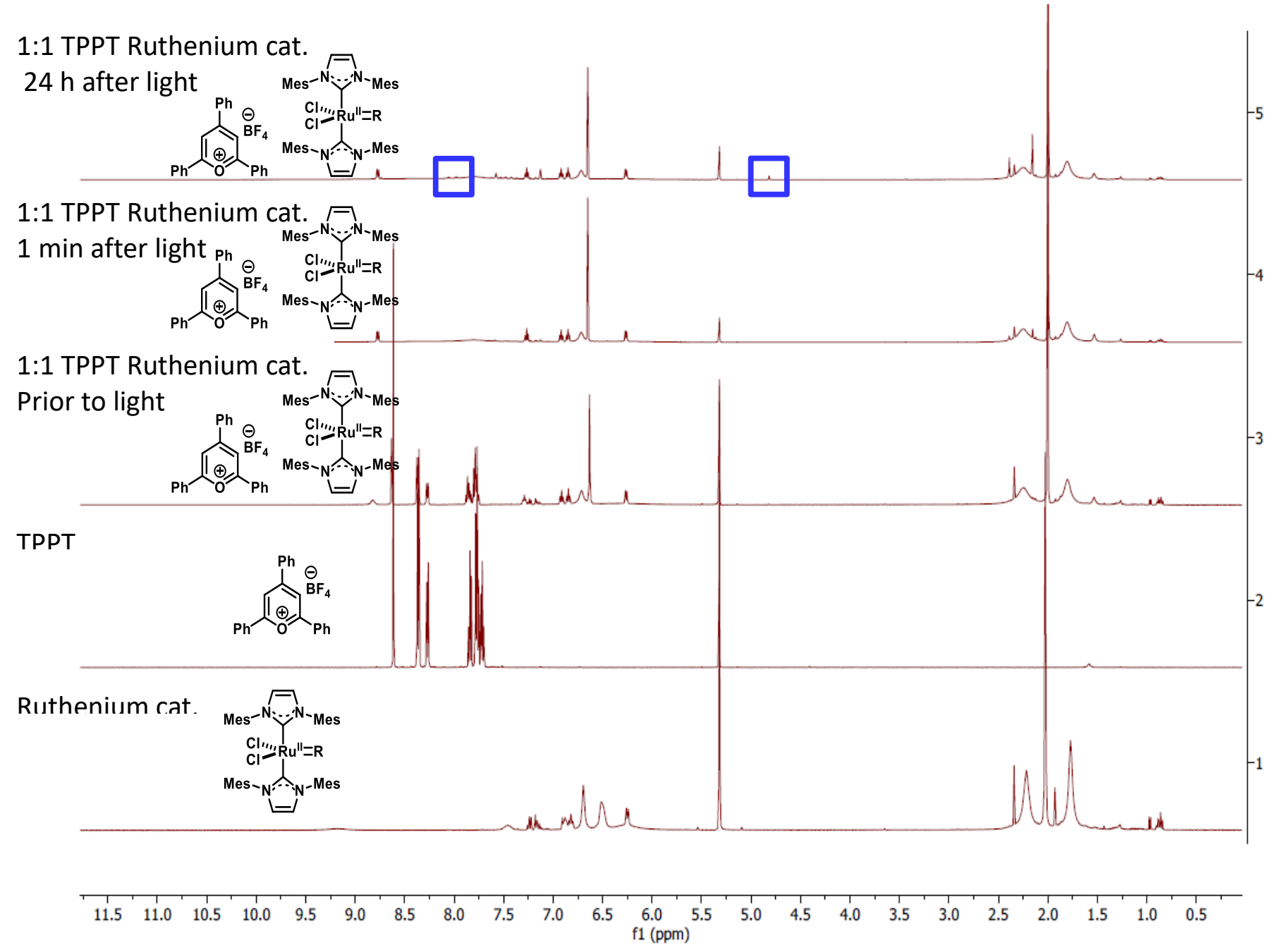


Diagnostic peaks suggesting complexation of TPPT to potentially form intermediate VII.

1:1 TPPT Ruthenium cat.

$24 \mathrm{~h}$ after light

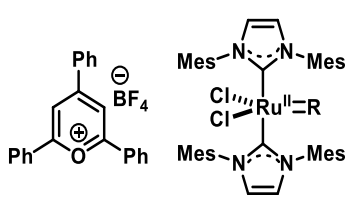

1:1 TPPT Ruthenium cat.

1 min after light

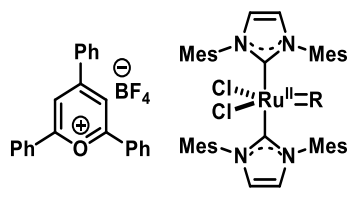

TPPT

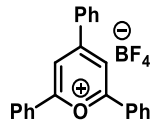

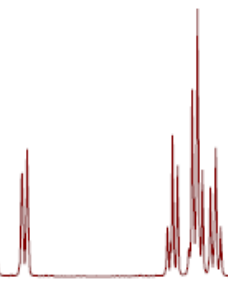

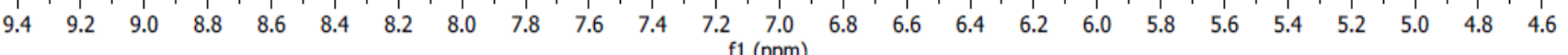


Kinetic NMR Spectroscopy of a 1:1 solution of TPPT and $\mathrm{RuCl}_{2}(\mathrm{CHPh})(\mathrm{IMes})_{2}$ in d-DCM.

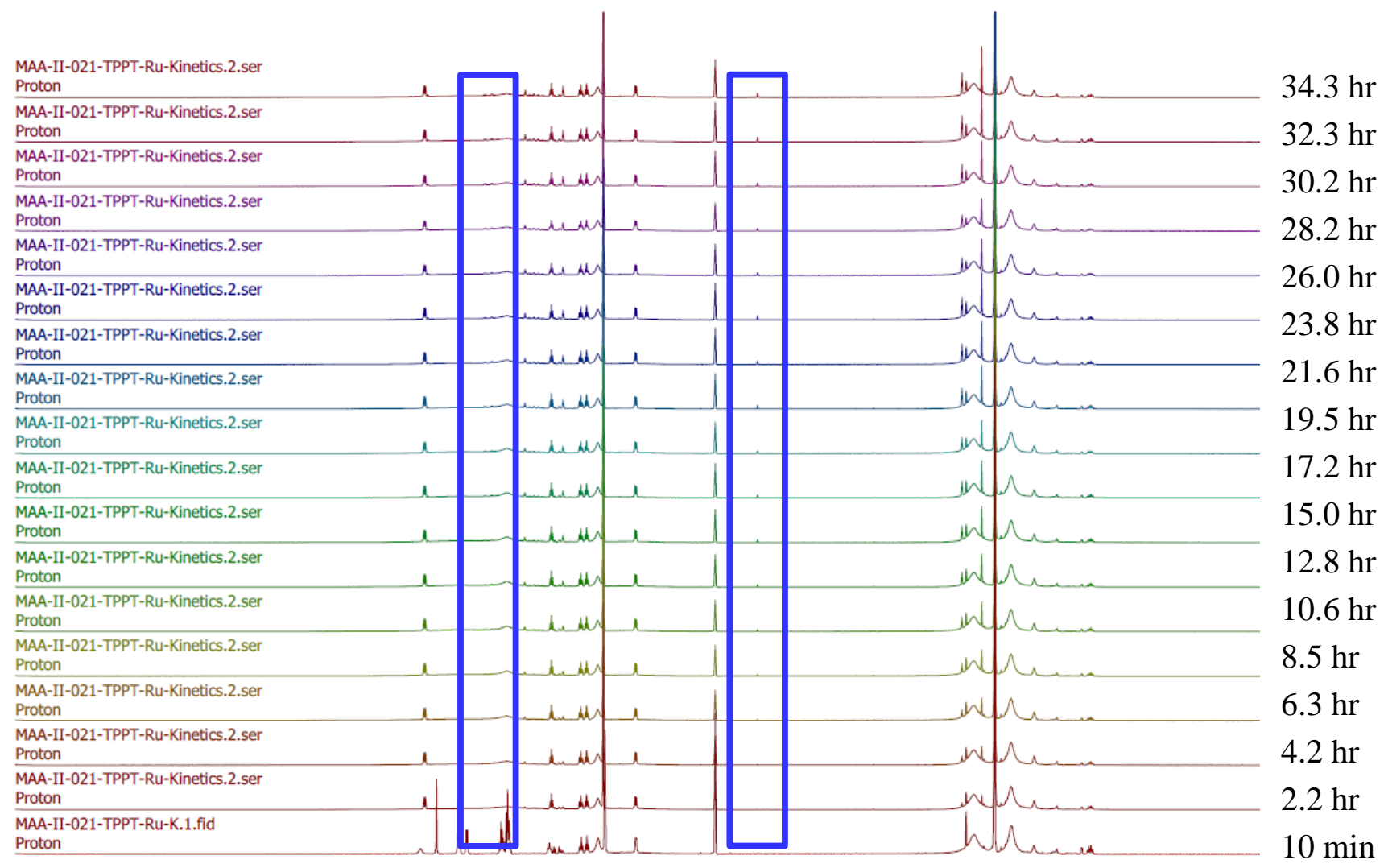

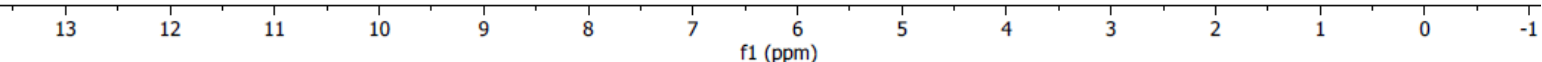




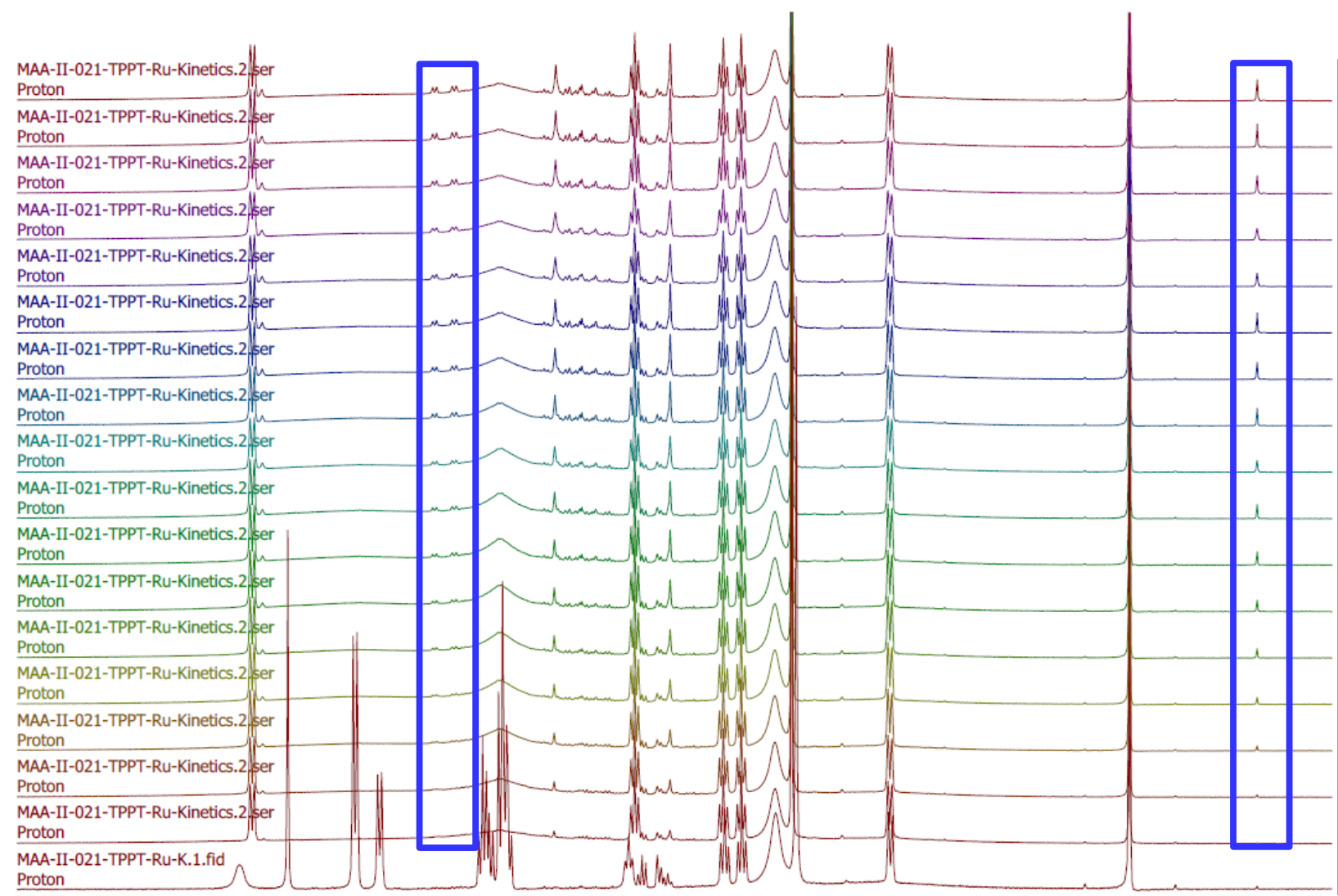

$34.3 \mathrm{hr}$ $32.3 \mathrm{hr}$ $30.2 \mathrm{hr}$ $28.2 \mathrm{hr}$ $26.0 \mathrm{hr}$ $23.8 \mathrm{hr}$ $21.6 \mathrm{hr}$ $19.5 \mathrm{hr}$ $17.2 \mathrm{hr}$ $15.0 \mathrm{hr}$ $12.8 \mathrm{hr}$ $10.6 \mathrm{hr}$ $8.5 \mathrm{hr}$ $6.3 \mathrm{hr}$ $4.2 \mathrm{hr}$ $2.2 \mathrm{hr}$ $10 \mathrm{~min}$

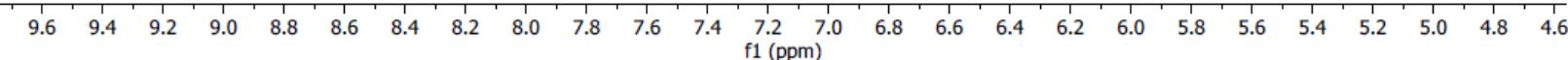




\section{Extended Optimization Studies:}

\section{Screening of Photocatalysts}

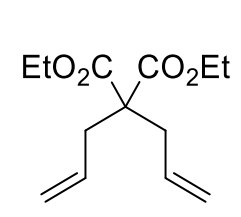

$(0.1 \mathrm{mmol})$

$\mathrm{RuCl}_{2}(\mathrm{CHPh})(\mathrm{IMes})_{2}$

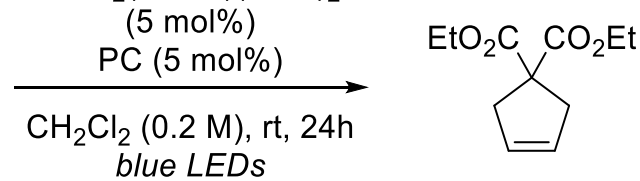

Photocatalyst

Excited state oxidation

Excited state energy

Yield potential (V vs SCE) $(\mathrm{kcal} / \mathrm{mol})$

\begin{tabular}{|c|c|c|c|}
\hline $\operatorname{Ir}(\mathrm{ppy})_{3}$ & 0.31 & 55.20 & 0 \\
\hline$\left[\operatorname{Ir}(\mathrm{ppy})_{2}(\mathrm{dtbbpy})\right] \mathrm{PF}_{6}$ & 0.66 & 49.21 & 0 \\
\hline $\mathrm{Ru}(\mathrm{bpy})_{3} \mathrm{Cl}_{2}$ & 0.77 & 46.49 & 0 \\
\hline Fluorescein & 0.77 & 44.74 & 0 \\
\hline Rose Bengal & 0.81 & 41.51 & 0 \\
\hline Eosin $Y$ & 0.83 & 44.05 & 0 \\
\hline Rhodamine B & 0.84 & 41.51 & 0 \\
\hline Rhodamine 6G & 0.95 & 48.20 & 0 \\
\hline$\left[\operatorname{Ir}\left(\mathrm{dF}-\mathrm{CF}_{3} \mathrm{ppy}\right)_{2}(\mathrm{dtbbpy})\right] \mathrm{PF}_{6}$ & 1.21 & 60.10 & 0 \\
\hline 4CZIPN & 1.35 & $\mathrm{n} / \mathrm{a}$ & 0 \\
\hline $\mathrm{Ru}(\mathrm{bpz})_{3} \mathrm{Cl}_{2}$ & 1.45 & 48.38 & 0 \\
\hline TAPT & 1.84 & $S_{1}: 53.96 ; T_{1}: 50.96$ & 0 \\
\hline $\mathrm{MesAcrPhBF}_{4}$ & 2.12 & $\mathrm{n} / \mathrm{a}$ & 33 \\
\hline $\mathrm{MesAcrMeClO}_{4}$ & 2.18 & $\mathrm{~S}_{1}: 61.57 ; \mathrm{T}_{1}: 44.74$ & 8 \\
\hline MesAcrMe BF 4 & 2.18 & $\mathrm{~S}_{1}: 61.57 ; \mathrm{T}_{1}: 44.74$ & 16 \\
\hline TPPT & 2.55 & $\mathrm{~S}_{1}: 65.26 ; \mathrm{T}_{1}: 53.04$ & 84 \\
\hline
\end{tabular}

Some known triplet sensitizers such as benzophenone, 4,4'-dimethoxybenzophenone, 4,4'bis(dimethylamino)benzophenone (or Michler's ketone) and 9-fluorenone have also been investigated to promote the ring closing metathesis of diallyl diethylmalonate. As for most photocatalysts displayed in the above chart, no reaction was observed. 


\section{On/Off Experiments}

On/off experiments were performed for the ring closing metathesis of diethyl diallylmalonate using $2 \mathrm{~mol} \%$ of $\mathrm{RuCl}_{2}(\mathrm{CHPh})(\mathrm{IMes})_{2}$ and $4 \mathrm{~mol} \%$ of 2,4,6-triphenylpyrylium tetrafluoroborate (TPPT) in $\mathrm{CH}_{2} \mathrm{Cl}_{2}(0.2 \mathrm{M})$ at room temperature over a period of time alternating cycles of irradiation and darkness. The reaction was conducted in the presence of mesitylene, used as internal standard. Aliquots were taken every hour and yields were determined by ${ }^{1} \mathrm{H}$ NMR.
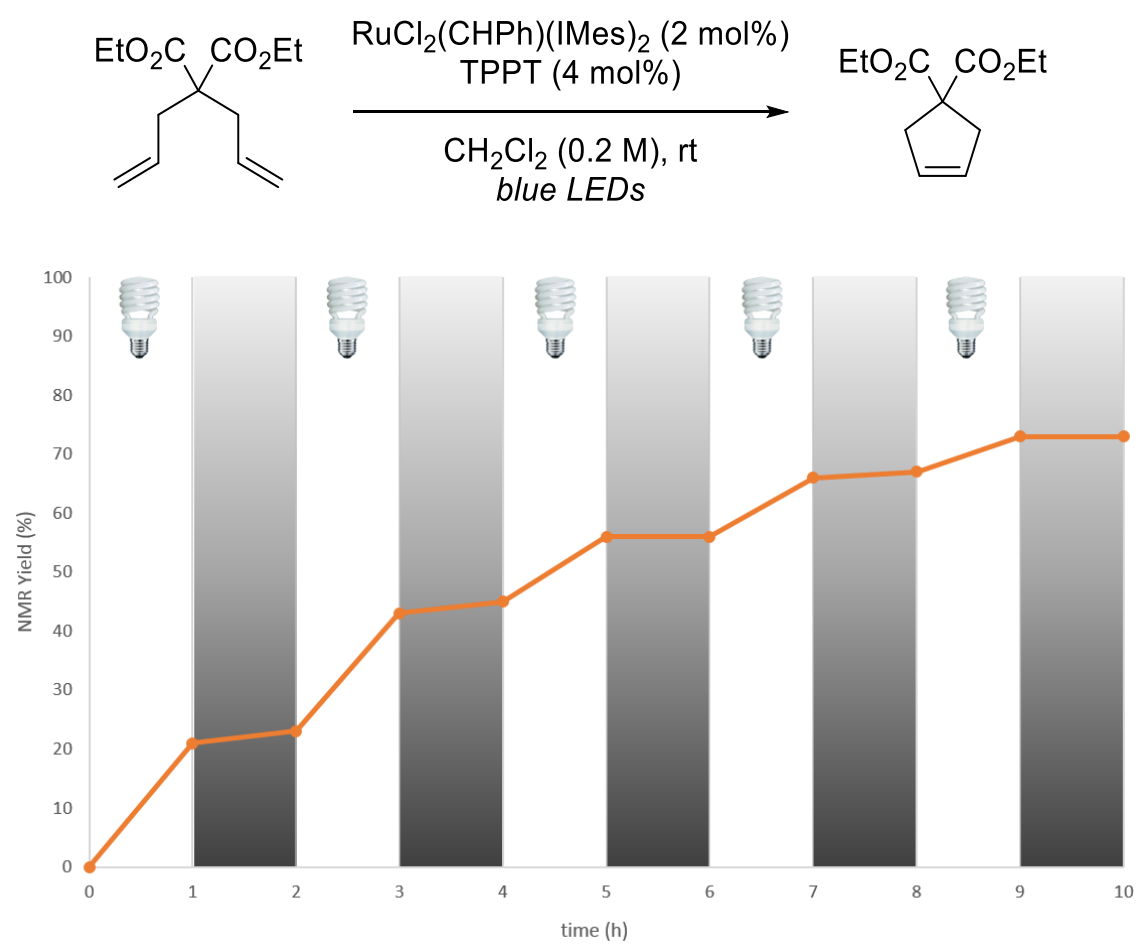


\section{Extended Substrate Scope}

These two tables display the entire scope for the synthesis of small molecules that has been studied under the conditions reported in this manuscript. The left table is reproduced below from the manuscript; additional examples may be found in the right table.

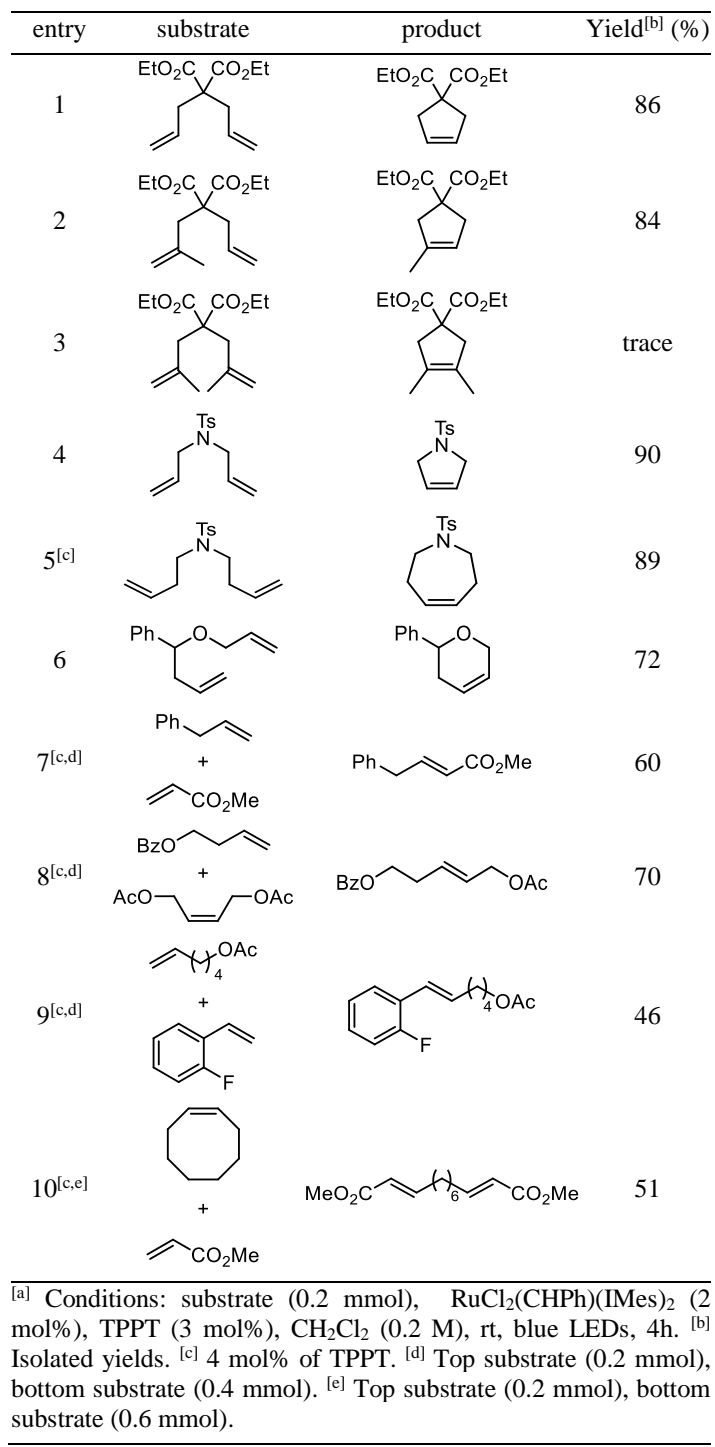

entry




\section{Experimental Setups}

\section{Experimental setup 1: visible-light-controlled olefin metathesis}

The experimental setup includes a magnetic stirrer placed in a cardboard box, two blue Kessil LED lamps $(440 \mathrm{~nm})$ as light sources and a fan to maintain the reaction mixture at room temperature. The Kessil lamps are placed at a distance of 5-10 cm from the vial.
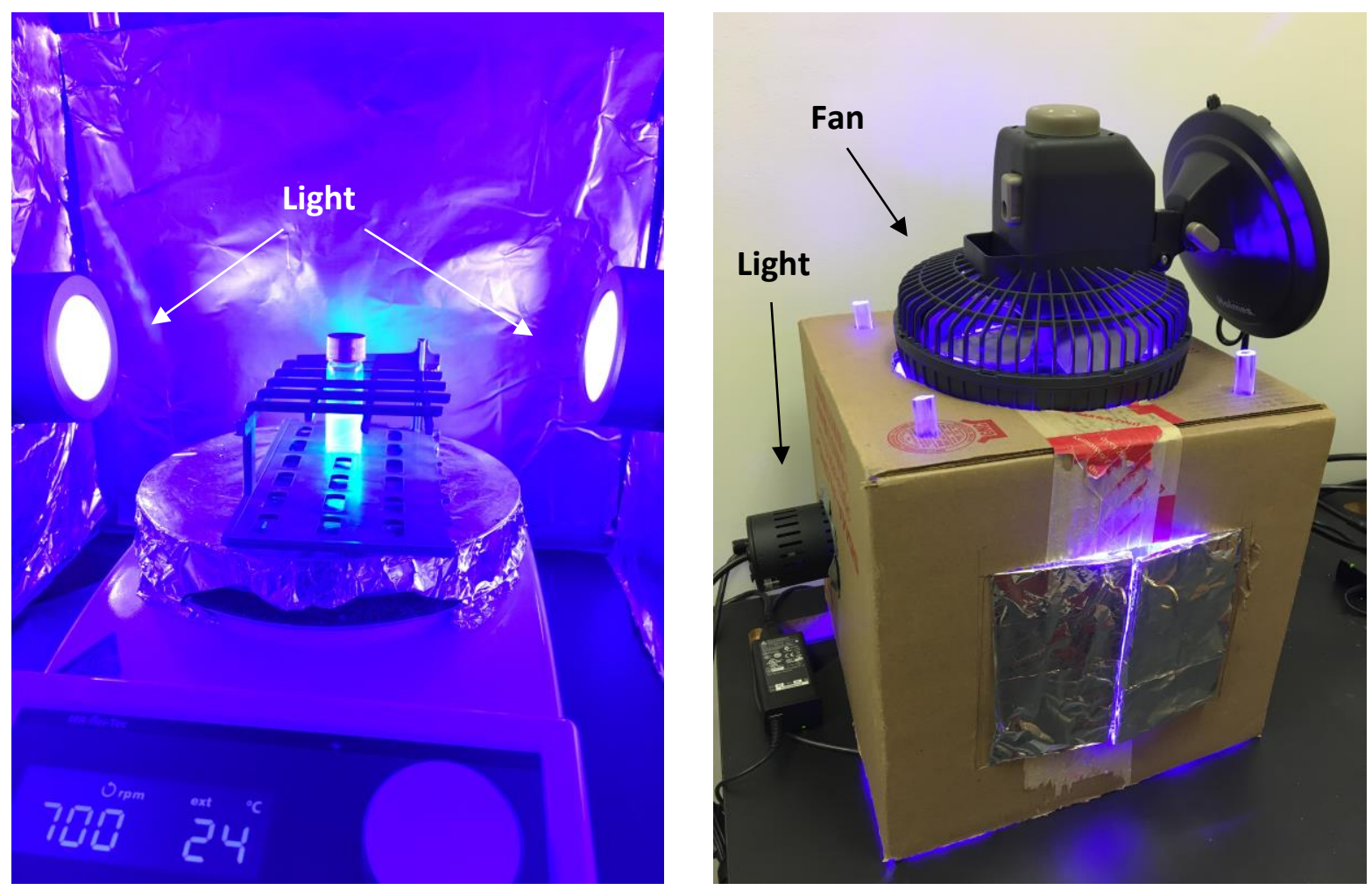


\section{Experimental setup 2: polymer patterning using macroscopic photomasks}

The polymer patterning experiments using macroscopic photomasks are conducted in a glovebox. The experimental setup includes: a BRAND ${ }^{\circledR}$ petri dish (glass) in which the polymerization is performed, a blue Kessil LED lamp (440 nm) as the light source, a black paper photomask with the appropriate pattern and a fan to maintain the reaction mixture at room temperature. The Kessil lamp is placed at a distance of 5-10 cm from the petri dish.
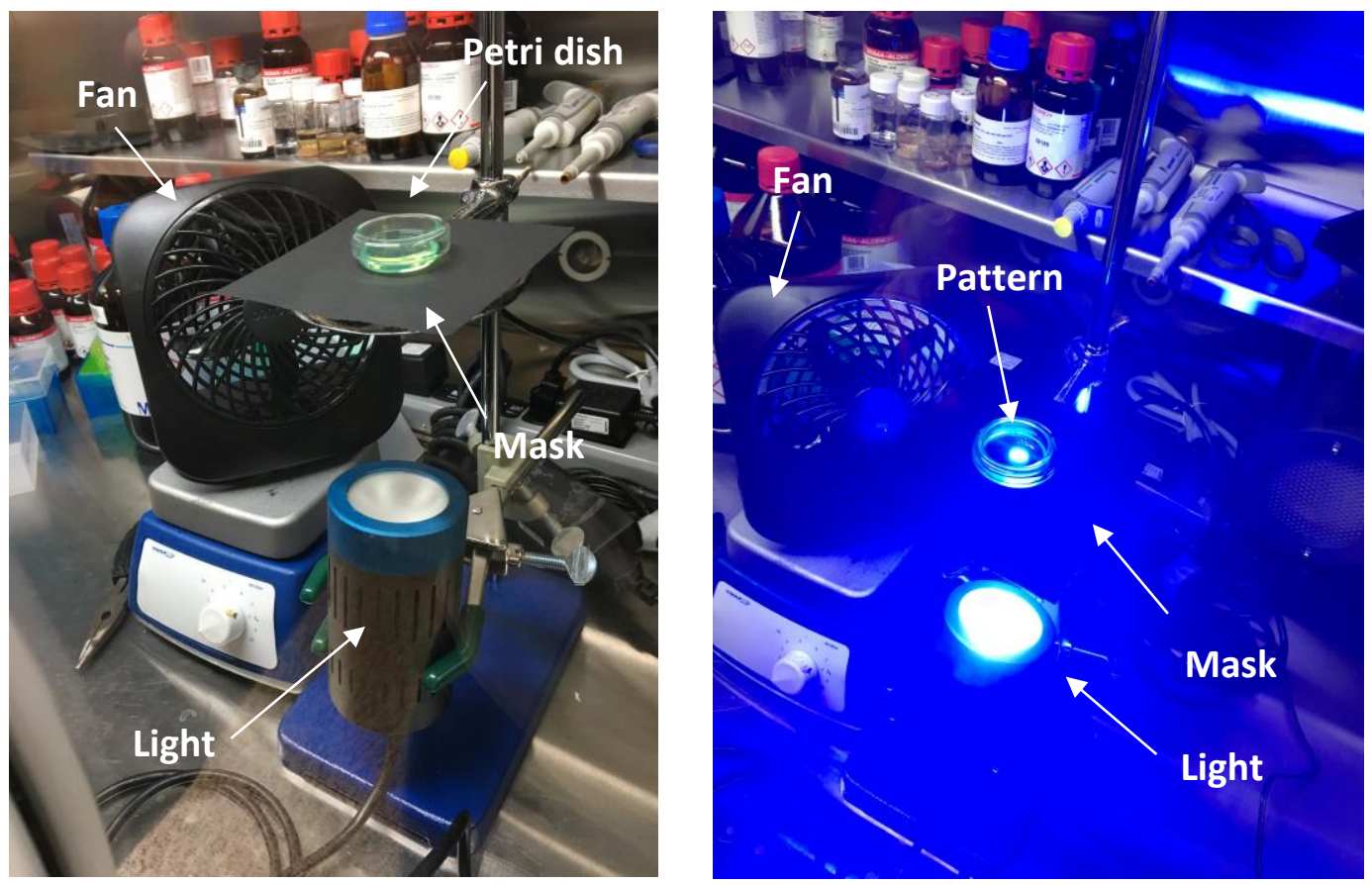

\section{Examples of photomasks}
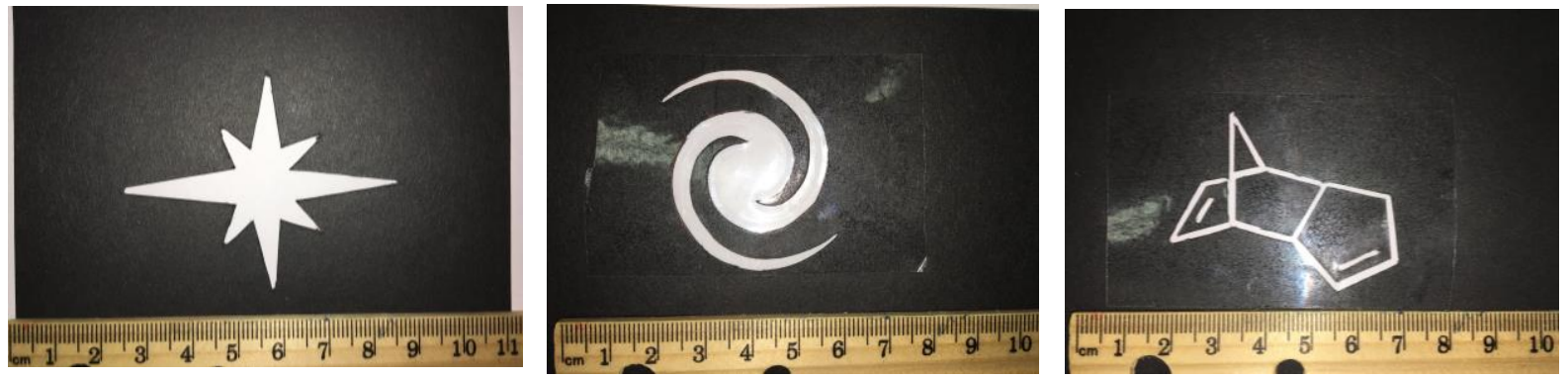


\section{Experimental setup 3: polymer patterning using blue laser}

The polymer patterning experiments using blue lasers are conducted in a glovebox. The experimental setup includes: a BRAND ${ }^{\circledR}$ petri dish (glass) in which the polymerization is performed, a blue laser pointer (450 nm, $200 \mathrm{~mW}$ ) as the light source and a magnifying glass to focus the laser beam. The support stand is moved either manually or with an orbital shaker to induce patterning. The blue laser is placed at a distance of 5-10 cm from the petri dish.

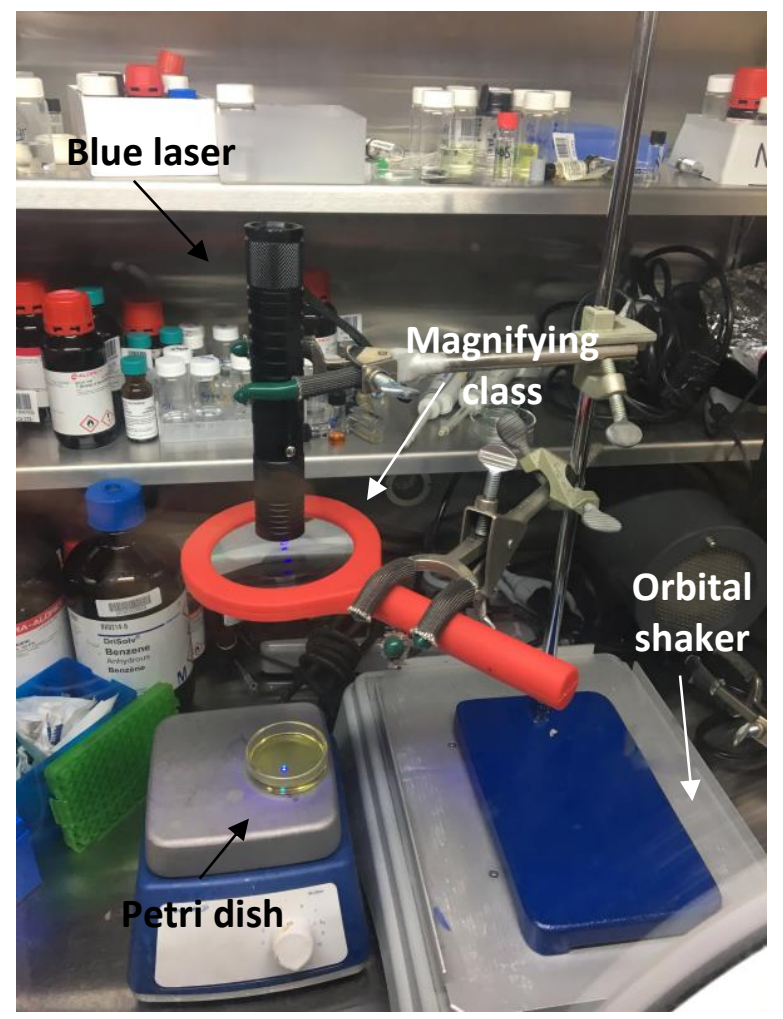




\section{Experimental setup 4: photolithography on silicon wafers}

The photolithographic experiments on silicon wafers are conducted in a glovebox. The experimental setup includes: a norbornene-pre-functionalized silicon wafer, two microscope slides (22 mm x $22 \mathrm{~mm}$, thickness of 0.13-0.17 mm), a blue Kessil LED lamp (440 nm) as the light source, a high resolution photomask and a fan to maintain the system at room temperature. The Kessil lamp is placed at a distance of $5-10 \mathrm{~cm}$ from the silicon wafer.
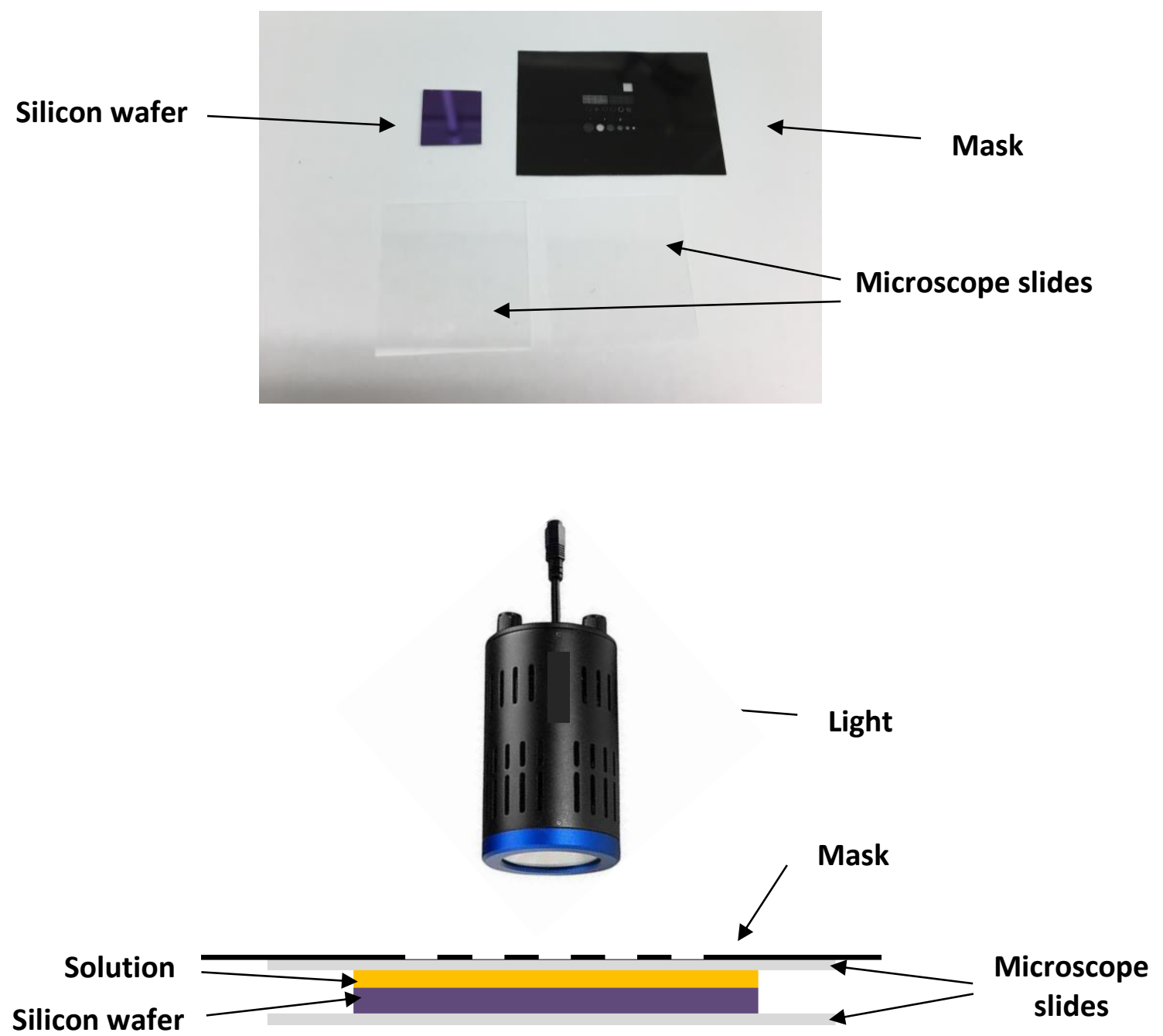


\section{Experimental Procedures and Characterization Data: Metathesis for the Synthesis of Small Molecules}

\section{General Procedure A: ring closing and enyne metathesis}

In a glovebox, an oven-dried 1-dram vial was charged with the substrate $(0.2 \mathrm{mmol})$, 2,4,6-triphenylpyrylium tetrafluoroborate TPPT (2.4 mg, $6 \mu \mathrm{mol}$ unless otherwise noted), $\mathrm{CH}_{2} \mathrm{Cl}_{2}$ $(1 \mathrm{~mL})$ and $\mathrm{RuCl}_{2}(\mathrm{CHPh})(\mathrm{IMes})_{2}(3.5 \mathrm{mg}, 4 \mu \mathrm{mol})$. The vial was tightly sealed and removed from the glovebox before stirring at room temperature under blue LEDs irradiation for $4 \mathrm{~h}$ (experimental setup 1). The reaction mixture was then concentrated under vacuum and purified by flash column chromatography over silica gel.

\section{General Procedure B: cross-metathesis}

In a glovebox, an oven-dried 1-dram vial was charged with the limiting olefin $(0.2 \mathrm{mmol})$, 2,4,6-triphenylpyrylium tetrafluoroborate TPPT (3.2 mg, $8 \mu \mathrm{mol}$ ), $\mathrm{CH}_{2} \mathrm{Cl}_{2}(1 \mathrm{~mL}$ ), the excess olefin (0.4 mmol) and $\mathrm{RuCl}_{2}(\mathrm{CHPh})(\mathrm{IMes})_{2}(3.5 \mathrm{mg}, 4 \mu \mathrm{mol})$. The vial was tightly sealed and removed from the glovebox before stirring at room temperature under blue LEDs irradiation for $4 \mathrm{~h}$ (experimental setup 1). The reaction mixture was then concentrated under vacuum and purified by flash column chromatography over silica gel.

\section{General Procedure C: ring opening - cross-metathesis}

In a glovebox, an oven-dried 1-dram vial was charged with the cyclic olefin $(0.2 \mathrm{mmol})$, 2,4,6-triphenylpyrylium tetrafluoroborate TPPT (3.2 mg, $8 \mu \mathrm{mol}), \mathrm{CH}_{2} \mathrm{Cl}_{2}(1 \mathrm{~mL})$, the terminal olefin $(0.6 \mathrm{mmol})$ and $\mathrm{RuCl}_{2}(\mathrm{CHPh})(\mathrm{IMes})_{2}(3.5 \mathrm{mg}, 4 \mu \mathrm{mol})$. The vial was tightly sealed and removed from the glovebox before stirring at room temperature under blue LEDs irradiation for $4 \mathrm{~h}$ (experimental setup 1). The reaction mixture was then concentrated under vacuum and purified by flash column chromatography over silica gel. 


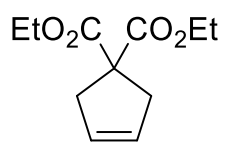

Diethyl cyclopent-3-ene-1,1-dicarboxylate. Prepared according to General Procedure A. Yield: 86\% (36.7 mg, $173 \mu \mathrm{mol}$ ) from diethyl diallylmalonate, 80\% (34.1 mg, 161 mmol) from diethyl 2allyl-2-(3-methylbut-2-en-1-yl)malonate and 85\% (36.2 mg, $170 \mu \mathrm{mol}$ ) from diethyl 2,2-bis-(but2-enyl)malonate. Solvent system for flash column chromatography: hexanes/EtOAc: 95/5; Pale yellow oil. This compound has been previously reported. ${ }^{9}$

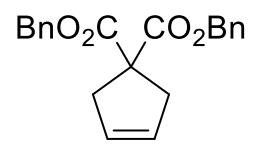

Dibenzyl cyclopent-3-ene-1,1-dicarboxylate. Prepared according to General Procedure A. Yield: 79\% (53.4 mg, $159 \mu \mathrm{mol})$. Solvent system for flash column chromatography: hexanes/EtOAc: 95/5; Colorless oil. ${ }^{1} \mathrm{H}$ NMR (500 MHz, $\left.\mathrm{CDCl}_{3}\right): \delta 7.36-7.24(\mathrm{~m}, 10 \mathrm{H}), 5.62(\mathrm{~s}, 2 \mathrm{H}), 5.14(\mathrm{~s}, 4 \mathrm{H}), 3.07$ (s, 4H); ${ }^{13} \mathrm{C} \mathrm{NMR}\left(125 \mathrm{MHz}, \mathrm{CDCl}_{3}\right): \delta 171.9,135.6,128.6,128.3,128.1,127.9,67.3,59.0,41.0$; IR (ATR): $V_{\max } 3063,2926,1756,1724,1459,1246,1163,1062,975,731,694,453 \mathrm{~cm}^{-1}$; ESIHRMS $\mathrm{m} / z$ calcd for $\mathrm{C}_{21} \mathrm{H}_{21} \mathrm{O}_{4}[\mathrm{M}+\mathrm{H}]^{+} 337.1434$, found 337.1440.

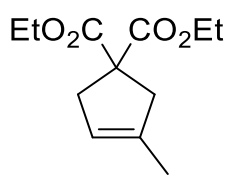

Diethyl 3-methylcyclopent-3-ene-1,1-dicarboxylate. Prepared according to General Procedure A. Yield: $84 \%(38.2 \mathrm{mg}, 169 \mu \mathrm{mol})$. Solvent system for flash column chromatography: hexanes/EtOAc: 95/5; Colorless oil. This compound has been previously reported. ${ }^{10}$

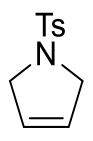


1-Tosyl-2,5-dihydro-1H-pyrrole. Prepared according to General Procedure A. Yield: 90\% (40.2 $\mathrm{mg}, 180 \mu \mathrm{mol})$. Solvent system for flash column chromatography: hexanes/EtOAc: 90/10; White solid. This compound has been previously reported. ${ }^{11}$<smiles>[As]N1CC=CCC1</smiles>

1-Tosyl-1,2,3,6-tetrahydropyridine. Prepared according to General Procedure A using $2 \mu \mathrm{mol}$ of $\mathrm{RuCl}_{2}(\mathrm{CHPh})(\mathrm{IMes})_{2}$ and $4 \mu \mathrm{mol}$ of TPPT. Yield: 74\% (35.3 mg, $\left.149 \mu \mathrm{mol}\right)$. Solvent system for flash column chromatography: hexanes/EtOAc: 90/10; White solid. This compound has been previously reported. ${ }^{12}$

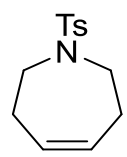

1-Tosyl-2,3,6,7-tetrahydro-1H-azepine. Prepared according to General Procedure A using $2 \mu \mathrm{mol}$ of $\mathrm{RuCl}_{2}(\mathrm{CHPh})(\mathrm{IMes})_{2}$ and $4 \mu \mathrm{mol}$ of TPPT. Yield: $89 \%$ (45.0 mg, $\left.179 \mu \mathrm{mol}\right)$. Solvent system for flash column chromatography: hexanes/EtOAc: 95/5; White solid. This compound has been previously reported. ${ }^{13}$

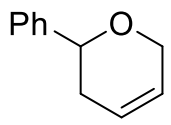

2-Phenyl-3,6-dihydro-2H-pyran. Prepared according to General Procedure A. Yield: 72\% (23.0 $\mathrm{mg}, 143 \mu \mathrm{mol})$. Solvent system for flash column chromatography: hexanes/EtOAc: 97/3; Colorless oil. This compound has been previously reported. ${ }^{14}$ 


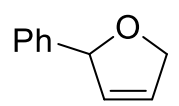

2-Phenyl-2,5-dihydrofuran. Prepared according to General Procedure A. Yield: 71\% (20.8 mg, $142 \mu \mathrm{mol})$. Solvent system for flash column chromatography: hexanes/EtOAc: 97/3; Colorless oil. This compound has been previously reported. ${ }^{15}$

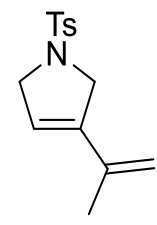

3-(Prop-1-en-2-yl)-1-tosyl-2,5-dihydro-1H-pyrrole. Prepared according to General Procedure A using $2 \mu \mathrm{mol}$ of $\mathrm{RuCl}_{2}(\mathrm{CHPh})(\mathrm{IMes})_{2}$ and $4 \mu \mathrm{mol}$ of TPPT. Yield: $40 \%$ (21.1 mg, $\left.80 \mu \mathrm{mol}\right)$. Solvent system for flash column chromatography: hexanes/EtOAc: 97/3; White solid. This compound has been previously reported. ${ }^{16}$

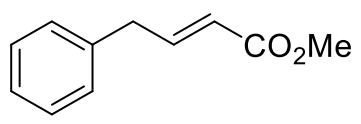

Methyl (E)-4-phenylbut-2-enoate. Prepared according to General Procedure B using allyl benzene $(0.2 \mathrm{mmol})$ and methyl acrylate $(0.4 \mathrm{mmol})$. Yield: 60\% $(21.3 \mathrm{mg}, 121 \mu \mathrm{mol})$. Solvent system for flash column chromatography: hexanes/EtOAc: 95/5; Pale yellow oil. This compound has been previously reported. ${ }^{17}$<smiles>CCCOC(=O)C=CCc1ccccc1</smiles>

tert-Butyl (E)-4-phenylbut-2-enoate. Prepared according to General Procedure B using allyl benzene $(0.2 \mathrm{mmol})$ and tert-butyl acrylate $(0.4 \mathrm{mmol})$. Yield: 50\% (22.0 mg, $101 \mu \mathrm{mol})$. Solvent system for flash column chromatography: hexanes/EtOAc: 95/5; Pale yellow oil. This compound has been previously reported. ${ }^{18}$ 


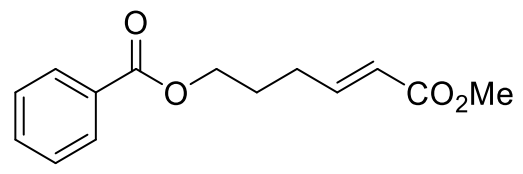

(E)-6-(tert-Butoxy)-6-oxohex-4-en-1-yl benzoate. Prepared according to General Procedure B using pent-4-en-1-yl benzoate $(0.2 \mathrm{mmol})$ and methyl acrylate $(0.4 \mathrm{mmol})$. Yield: $52 \%$ (25.8 $\mathrm{mg}$, $104 \mu \mathrm{mol})$. Solvent system for flash column chromatography: hexanes/EtOAc: 90/10; Yellow oil. This compound has been previously reported. ${ }^{19}$

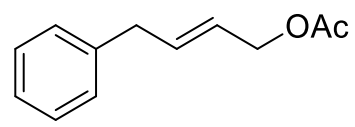

(E)-4-Phenylbut-2-en-1-yl acetate. Prepared according to General Procedure B using allyl benzene $(0.2 \mathrm{mmol})$ and cis-1,4-diacetoxy-2-butene $(0.4 \mathrm{mmol})$. Yield: 60\% (E/Z: 9/1, $23.0 \mathrm{mg}$, $121 \mu \mathrm{mol})$. Solvent system for flash column chromatography: hexanes/EtOAc: 95/5; Colorless oil. This compound has been previously reported. ${ }^{20}$

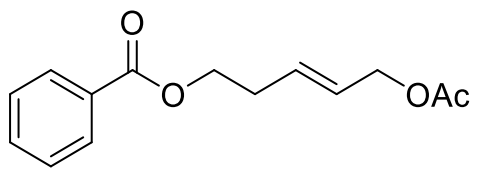

(E)-5-Acetoxypent-3-en-1-yl benzoate. Prepared according to General Procedure B using but-3en-1-yl benzoate $(0.2 \mathrm{mmol})$ and cis-1,4-diacetoxy-2-butene $(0.4 \mathrm{mmol})$. Yield: 70\% (E/Z : 9/1, $34.9 \mathrm{mg}, 703 \mu \mathrm{mol})$. Solvent system for flash column chromatography: hexanes/EtOAc: 85/15; Colorless oil; ${ }^{1} \mathrm{H}$ NMR (500 MHz, $\mathrm{CDCl}_{3}$ ): $E$ isomer $\delta 8.05$ (app. d, $J=8.3 \mathrm{~Hz}, 2 \mathrm{H}$ ), 7.58 (app. tt, $J=$ 7.4 and $1.3 \mathrm{~Hz}, 1 \mathrm{H}), 7.46(\mathrm{t}, J=8.1 \mathrm{~Hz}, 2 \mathrm{H}), 5.85(\mathrm{dtt}, J=15.5,6.6$ and $1.2 \mathrm{~Hz}, 1 \mathrm{H}$ ), 5.75 (dtt, $J$ $=15.5,6.3$ and $1.3 \mathrm{~Hz}, 1 \mathrm{H}), 4.55(\mathrm{dd}, J=6.3$ and $0.9 \mathrm{~Hz}, 2 \mathrm{H}), 4.39(\mathrm{t}, J=6.5 \mathrm{~Hz}, 2 \mathrm{H}), 2.56(\mathrm{qd}, J=$ 6.7 and $1.1 \mathrm{~Hz}, 2 \mathrm{H}), 2.06$ (s, 3H); ${ }^{13} \mathrm{C} \mathrm{NMR}\left(75 \mathrm{MHz}, \mathrm{CDCl}_{3}\right): \delta 170.9,166.6,133.2,131.1,130.4$, 129.7, 128.4, 127.0, 64.9, 63.8, 31.9, 21.1; IR (ATR): $v_{\max } 2939,1717,1451,1379,1271,1229$, 1111, 1026, 968, $712 \mathrm{~cm}^{-1}$; ESIHRMS $\mathrm{m} / \mathrm{z}$ calcd for $\mathrm{C}_{14} \mathrm{H}_{16} \mathrm{O}_{4} \mathrm{Na}[\mathrm{M}+\mathrm{Na}]^{+}$271.0941, found 271.0946 . 


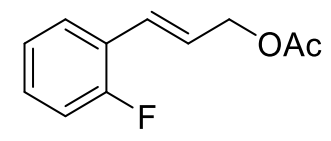

(E)-3-(2-Fluorophenyl)allyl acetate. Prepared according to General Procedure B using 2fluorostyrene (0.2 mmol) and cis-1,4-diacetoxy-2-butene (0.4 mmol). Yield: 51\% (20.1 mg, 103 $\mu \mathrm{mol})$. Solvent system for flash column chromatography: hexanes/EtOAc: 90/10; Colorless oil. This compound has been previously reported. ${ }^{21}$

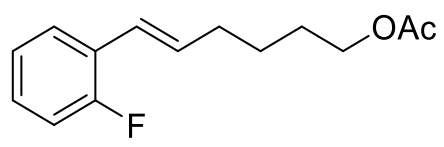

(E)-6-(2-Fluorophenyl)hex-5-en-1-yl acetate. Prepared according to General Procedure B using 2-fluorostyrene (0.2 mmol) and hex-5-en-1-yl acetate (0.4 mmol). Yield: 46\% (21.7 mg, 92 umol). Solvent system for flash column chromatography: hexanes/EtOAc: 96/4; Colorless oil; ${ }^{1} \mathrm{H}$ NMR $\left(500 \mathrm{MHz} \mathrm{CDCl}_{3}\right): \delta 7.42(\mathrm{td}, J=7.7$ and $1.7 \mathrm{~Hz}, 1 \mathrm{H}), 7.19-7.13(\mathrm{~m}, 1 \mathrm{H}), 7.06(\mathrm{td}, J=7.4$ and 1.0 $\mathrm{Hz}, 1 \mathrm{H}), 7.00(\mathrm{ddd}, J=10.9,8.1$ and $1.1 \mathrm{~Hz}, 1 \mathrm{H}), 6.55(\mathrm{~d}, J=15.8 \mathrm{~Hz}, 1 \mathrm{H}), 6.28(\mathrm{dt}, J=15.9$ and $7.1 \mathrm{~Hz}, 1 \mathrm{H}), 4.09(\mathrm{t}, J=6.6 \mathrm{~Hz}, 2 \mathrm{H}), 2.27(\mathrm{qd}, J=7.4$ and $1.2 \mathrm{~Hz}, 2 \mathrm{H}), 2.05(\mathrm{~s}, 3 \mathrm{H}), 1.73-1.66(\mathrm{~m}$, 2H), 1.59-1.52 (m, 2H); $\left.{ }^{13} \mathrm{C} \mathrm{NMR} \mathrm{(125} \mathrm{MHz,} \mathrm{CDCl}_{3}\right): \delta 171.3,160.0$ (d, $\left.J=246.6 \mathrm{~Hz}\right), 133.0(\mathrm{~d}, J=$ $4.3 \mathrm{~Hz}$ ), 128.2 (d, J = 8.3 Hz), 127.1 (d, J = 3.8 Hz), 125.5 (d, J = 12.3 Hz), 124.1 (d, J = 3.5 Hz), 122.8 (d, $J=3.6 \mathrm{~Hz}), 115.7$ (d, $J=22.1 \mathrm{~Hz}), 64.4,33.0,28.2,25.7,21.1 ;{ }^{19} \mathrm{~F} \mathrm{NMR}\left(470 \mathrm{MHz}, \mathrm{CDCl}_{3}\right): \delta$ 119.4 (m); IR (ATR): $v_{\max } 2934,1736,1486,1365,1233,1037,969,754,606 \mathrm{~cm}^{-1}$; ESIHRMS m/z calcd for $\mathrm{C}_{14} \mathrm{H}_{17} \mathrm{FO}_{2} \mathrm{Na}[\mathrm{M}+\mathrm{Na}]^{+} 259.1105$, found 259.1110 .

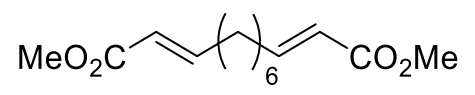

Dimethyl (2E,10E)-dodeca-2,10-dienedioate. Prepared according to General Procedure C using cis-cyclooctene $(0.2 \mathrm{mmol})$ and methyl acrylate $(0.6 \mathrm{mmol})$. Yield: 51\% (26.0 mg, $102 \mu \mathrm{mol})$. Solvent system for flash column chromatography: hexanes/EtOAc: 90/10; Pale yellow oil; ${ }^{1} \mathrm{H}$ NMR (500 MHz, $\left.\mathrm{CDCl}_{3}\right): \delta 6.95(\mathrm{dt}, J=15.5$ and $6.9 \mathrm{~Hz}, 2 \mathrm{H}), 5.81(\mathrm{dt}, J=15.6$ and $1.5 \mathrm{~Hz}, 2 \mathrm{H}), 3.72(\mathrm{~s}$, 
$6 \mathrm{H}), 2.19(\mathrm{qd}, J=7.2$ and $1.5 \mathrm{~Hz}, 4 \mathrm{H}), 1.49-1.40(\mathrm{~m}, 4 \mathrm{H}), 1.36-1.27(\mathrm{~m}, 4 \mathrm{H}) ;{ }^{13} \mathrm{C}$ NMR $(125 \mathrm{MHz}$, $\left.\mathrm{CDCl}_{3}\right): \delta 167.3,149.7,121.1,51.5,32.2,29.0,28.0$; IR (ATR): $v_{\max } 2927,2854,1721,1656,1435$, $1269,1195,1178,1038,980,716 \mathrm{~cm}^{-1}$; ESIHRMS $\mathrm{m} / z$ calcd for $\mathrm{C}_{14} \mathrm{H}_{23} \mathrm{O}_{4}[\mathrm{M}+\mathrm{H}]^{+} 255.1591$, found 255.1596.

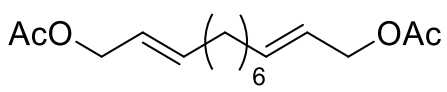

(2E,10E)-Dodeca-2,10-diene-1,12-diyl diacetate. Prepared according to General Procedure C using cis-cyclooctene $(0.2 \mathrm{mmol})$ and cis-1,4-diacetoxy-2-butene $(0.6 \mathrm{mmol})$. Yield: 53\% (E,E/E,Z: 9/1, $30.0 \mathrm{mg}, 106 \mu \mathrm{mol})$. Solvent system for flash column chromatography: hexanes/EtOAc: 95/5; Colorless oil; ${ }^{1} \mathrm{H}$ NMR (500 MHz, $\mathrm{CDCl}_{3}$ ): $E / E$ isomer $\delta 5.76$ (app. dt, $J=15.3$ and $6.8 \mathrm{~Hz}, 2 \mathrm{H}$ ), 5.55 (dtt, $J=15.3,6.5$ and $1.3 \mathrm{~Hz}, 2 \mathrm{H}$ ), 4.50 (dd, $J=6.5$ and $0.7 \mathrm{~Hz}, 4 \mathrm{H}$ ), 2.07-2.01 (m, 4H), 2.06 (obs. $\mathrm{s}, 6 \mathrm{H}), 1.42-1.33(\mathrm{~m}, 4 \mathrm{H}), 1.32-1.25(\mathrm{~m}, 4 \mathrm{H}) ;{ }^{13} \mathrm{C} \mathrm{NMR}\left(125 \mathrm{MHz}, \mathrm{CDCl}_{3}\right): \delta 171.0,136.7,123.9$, 65.5, 32.3, 29.1, 28.9, 21.2; IR (ATR): $v_{\max } 2926,2854,1737,1446,1363,1228,1023,965,698$, $607 \mathrm{~cm}^{-1}$; ESIHRMS m/z calcd for $\mathrm{C}_{16} \mathrm{H}_{26} \mathrm{O}_{4} \mathrm{Na}[\mathrm{M}+\mathrm{Na}]^{+} 305.1723$, found 305.1729.

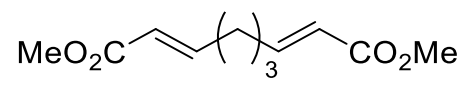

Dimethyl (2E,7E)-nona-2,7-dienedioate. Prepared according to General Procedure C using cyclopentene $(0.2 \mathrm{mmol})$ and methyl acrylate $(0.6 \mathrm{mmol})$. Yield: 58\% (24.5 mg, $115 \mu \mathrm{mol})$. Solvent system for flash column chromatography: hexanes/EtOAc: 90/10; Pale yellow oil. This compound has been previously reported. ${ }^{22}$ 


\section{Experimental Procedure and Characterization Data: \\ Ring Opening Metathesis Polymerization}

\section{General Procedure}

In a glovebox, an oven-dried 1-dram vial was charged with the monomer $(0.2 \mathrm{mmol})$, 2,4,6-triphenylpyrylium tetrafluoroborate TPPT (0.79 $\mathrm{mg}, 2 \mu \mathrm{mol}), \mathrm{CD}_{2} \mathrm{Cl}_{2}(1 \mathrm{~mL})$ and $\mathrm{RuCl}_{2}(\mathrm{CHPh})(\mathrm{IMes})_{2}(0.87 \mathrm{mg}, 1 \mu \mathrm{mol})$. Mesitylene $(27.8 \mu \mathrm{L}, 0.2 \mathrm{mmol})$ was added and used as internal standard to monitor conversion. The vial was tightly sealed and removed from the glovebox before stirring at room temperature under blue LEDs irradiation for $1 \mathrm{~h}$ (experimental setup 1). The reaction mixture was then poured into methanol and the desired polymer was finally isolated by filtration, washed thoroughly with methanol and pentane and dried under vacuum.

Dicyclopentadiene was polymerized using $0.1 \mu \mathrm{mol}$ of $\mathrm{RuCl}_{2}(\mathrm{CHPh})(\mathrm{IMes})_{2}$ and $0.5 \mu \mathrm{mol}$ of TPPT during 15 minutes.

Poly[bicyclo[2.2.1]hept-2-ene] 1. Conversion: $>95 \% .{ }^{1} \mathrm{H}$ NMR $\left(500 \mathrm{MHz}, \mathrm{CDCl}_{3}\right): \delta 5.34$ (br. s, $\left.1 \mathrm{H}\right)$, 5.21 (br. s, 1H), 2.79 (br. s, 1H), 2.43 (br. s, 1H), 1.96-1.68 (m, 3H), 1.35 (br. s, 2H), 1.12-0.93 (m, $1 \mathrm{H})$.

Poly[exo,exo-dibenzyl bicyclo[2.2.1]hept-5-ene-2,3-dicarboxylate] 2. Conversion: $>95 \%$. ${ }^{1} \mathrm{H}$ NMR (500 MHz, $\left.\mathrm{CDCl}_{3}\right): \delta 7.30-7.15(\mathrm{~m}, 10 \mathrm{H}), 5.39-5.10(\mathrm{~m}, 2 \mathrm{H}), 5.00-4.70(\mathrm{~m}, 4 \mathrm{H}), 3.56-3.28(\mathrm{~m}$, $1 \mathrm{H}), 3.07-2.68(\mathrm{~m}, 3 \mathrm{H}), 2.30-1.80(\mathrm{~m}, 1 \mathrm{H}), 1.28-0.99(\mathrm{~m}, 1 \mathrm{H})$.

Poly[exo,exo-7-oxabicyclo[2.2.1]hept-5-ene-2,3-diylbis(methylene) diacetate] 3. Conversion: $>95 \%$. ${ }^{1} \mathrm{H}$ NMR $\left(500 \mathrm{MHz}, \mathrm{CDCl}_{3}\right): \delta 5.79-5.52(\mathrm{~m}, 2 \mathrm{H}), 4.49$ (br. s, $\left.1 \mathrm{H}\right), 4.24-4.07(\mathrm{~m}, 5 \mathrm{H}), 2.06-$ $2.01(\mathrm{~m}, 6 \mathrm{H})$.

Poly[(bicyclo[2.2.1] hept-5-en-2-yloxy)(tert-butyl)dimethylsilane] 4. Conversion: $>95 \% .{ }^{1} \mathrm{H}$ NMR $\left(500 \mathrm{MHz}, \mathrm{CDCl}_{3}\right): \delta 5.47-5.09(\mathrm{~m}, 2 \mathrm{H}), 3.63-3.31(\mathrm{~m}, 2 \mathrm{H}), 3.02-2.32(\mathrm{~m}, 2 \mathrm{H}), 2.21-1.65(\mathrm{~m}, 3 \mathrm{H})$, 1.52-1.04 (m, 2H), 0.89 (br. s, 9H), 0.02 (br. s, 6H). 


\section{Estimation of the $k_{\text {rel }}$ light/dark for the polymerization of dicyclopentadiene 12}

Following the general procedure described above, polymerization of dicyclopentadiene was performed under blue LED irradiation, stopped after 90 seconds and immediately quenched by addition of excess ethyl vinyl ether. Analysis of the crude reaction mixture by ${ }^{1} \mathrm{H}$ NMR showed $16 \%$ polymerization, which corresponds to $10.666 \%$ polymerization per minute (Experiment 1 ). Additionally, polymerization of dicyclopentadiene has also been performed with the reaction mixtures being maintained in the dark (wrapped with thin foil). The reaction mixtures were stirred in the dark for $24 \mathrm{~h}$ (less than $5 \%$ polymerization observed), 3 days ( $5 \%$ polymerization observed) or 7 days ( $9 \%$ polymerization observed). From the last experiments ( $9 \%$ polymerization observed after 7 days), we can estimate the rate of polymerization in the dark to be $9 \times 10^{-4} \%$ polymerization per minute. The ratio between Experiment 2 and $4\left(10.6666 / 9 \times 10^{-4}\right)$ gives a krel light/dark of 12,000 . 


\section{Experimental Procedures and Results: \\ Polymer Patterning using Masks}

All patterning experiments were run in a glovebox to exclude oxygen and ensure good reproducibility. Importantly, performing the reaction outside the glovebox with no other precautions than flushing the reaction mixture with an argon flow gave identical results.

\section{General Procedures}

- Dicyclopentadiene $\mathbf{1 2}$ as monomer

In a glovebox, an oven-dried $20 \mathrm{~mL}$ scintillation vial was charged with 2,4,6-triphenylpyrylium tetrafluoroborate TPPT (2.0 mg, $5 \mu \mathrm{mol}), \mathrm{CH}_{2} \mathrm{Cl}_{2}(3 \mathrm{~mL})$ and $\mathrm{RuCl}_{2}(\mathrm{CHPh})(\mathrm{IMes})_{2}(0.87 \mathrm{mg}, 1 \mu \mathrm{mol})$. Dicyclopentadiene $(1.32 \mathrm{~g}, 10 \mathrm{mmol})$ was then added and the solution was transferred into a BRAND $^{\circledast}$ petri dish (glass, $40 \mathrm{~mm} \times 12 \mathrm{~mm}$ ). The petri dish was placed on the mask and light was shined through the mask for 15 minutes (experimental setup 2). The petri dish was finally removed from the glovebox and the unreacted monomer was thoroughly washed away with dichloromethane to afford the desired patterned poly(dicyclopentadiene).

When the patterning experiments were performed on a bigger scale, the amounts of dicyclopentadiene, catalysts, dichloromethane and the size of the petri dish were adjusted as followed: dicyclopentadiene (7.93 $\mathrm{g}, 60 \mathrm{mmol}), \mathrm{RuCl}_{2}(\mathrm{CHPh})(\mathrm{IMes})_{2}(5.2 \mathrm{mg}, 6 \mathrm{~mol})$, 2,4,6-triphenylpyrylium tetrafluoroborate TPPT (11.9 mg, $30 \mu \mathrm{mol}$ ) and $\mathrm{CH}_{2} \mathrm{Cl}_{2}(26 \mathrm{~mL})$ in a BRAND ${ }^{\circledR}$ petri dish (glass, $80 \mathrm{~mm} \times 15 \mathrm{~mm}$ ). Light was shined for 30 minutes.

- Norbornadiene 9 as monomer

In a glovebox, an oven-dried $20 \mathrm{~mL}$ scintillation vial was charged with 2,4,6-triphenylpyrylium tetrafluoroborate TPPT $(5.9 \mathrm{mg}, 15 \mu \mathrm{mol}), \mathrm{CH}_{2} \mathrm{Cl}_{2}(2.5 \mathrm{~mL})$ and $\mathrm{RuCl}_{2}(\mathrm{CHPh})(\mathrm{IMes})_{2}(6.5 \mathrm{mg}, 7.5$ $\mu \mathrm{mol})$. Norbornadiene $(1.52 \mathrm{~mL}, 15 \mathrm{mmol})$ was then added and the solution was transferred into a BRAND ${ }^{\circledR}$ petri dish (glass, $40 \mathrm{~mm} \times 12 \mathrm{~mm}$ ). The petri dish was placed on the mask and light was 
shined through the mask for $1 \mathrm{~h}$ (experimental setup 2). The petri dish was finally removed from the glovebox and the unreacted monomer was thoroughly washed away with dichloromethane to afford the desired patterned poly(norbornadiene).

- 1,5-Cyclooctadiene $\mathbf{1 0}$ as monomer

In a glovebox, an oven-dried $20 \mathrm{~mL}$ scintillation vial was charged with 2,4,6-triphenylpyrylium tetrafluoroborate TPPT (5.0 mg, $12.5 \mu \mathrm{mol}), \mathrm{CH}_{2} \mathrm{Cl}_{2}\left(2.5 \mathrm{~mL}\right.$ ) and $\mathrm{RuCl}_{2}$ (CHPh)(IMes) 2 (5.4 mg, 6.25 umol). 1,5-Cyclooctadiene $(1.53 \mathrm{~mL}, 12.5 \mathrm{mmol})$ was then added and the solution was transferred into a BRAND ${ }^{\circledR}$ petri dish (glass, $40 \mathrm{~mm} \times 12 \mathrm{~mm}$ ). The petri dish was placed on the mask and light was shined through the mask for 15 minutes (experimental setup 2). The petri dish was finally removed from the glovebox and the unreacted monomer was thoroughly washed away with dichloromethane to afford the desired patterned poly(1,5-cyclooctadiene).

- 5-Ethylidene-2-norbornene $\mathbf{1 1}$ as monomer

In a glovebox, an oven-dried $20 \mathrm{~mL}$ scintillation vial was charged with 2,4,6-triphenylpyrylium tetrafluoroborate TPPT $(4.0 \mathrm{mg}, 10 \mu \mathrm{mol}), \mathrm{CH}_{2} \mathrm{Cl}_{2}(2.5 \mathrm{~mL})$ and $\mathrm{RuCl}_{2}(\mathrm{CHPh})(\mathrm{IMes})_{2}(4.3 \mathrm{mg}, 5$ umol). 5-Ethylidene-2-norbornene $(1.34 \mathrm{~mL}, 10 \mathrm{mmol})$ was then added and the solution was transferred into a BRAND ${ }^{\circledR}$ petri dish (glass, $40 \mathrm{~mm} \times 12 \mathrm{~mm}$ ). The petri dish was placed on the mask and light was shined through the mask for 15 minutes (experimental setup 2). The petri dish was finally removed from the glovebox and the unreacted monomer was thoroughly washed away with dichloromethane to afford the desired patterned poly(5-ethylidene-2-norbornene). 


\section{Results}

- $\quad$ Pictures of patterned poly(12, 9, 10 and $\mathbf{1 1})$
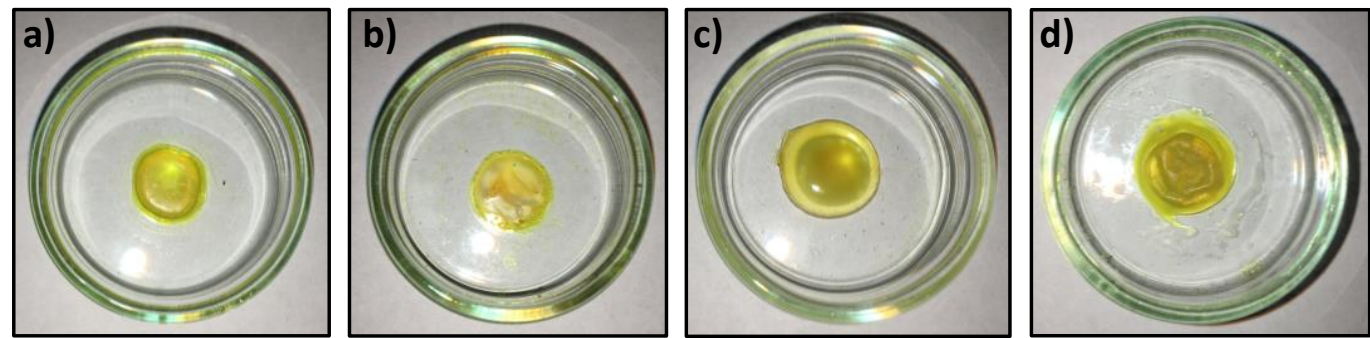

Pictures of (a) poly(dicyclopentadiene 12), (b) poly(norbornadiene 9), (c) poly(1,5-cyclooctadiene 10), (d) poly(5-ethylidene-2norbornene 11) in $40 \mathrm{~mm} \times 12 \mathrm{~mm}$ petri dishes.

- Pictures of more sophisticated patterns of poly(12)
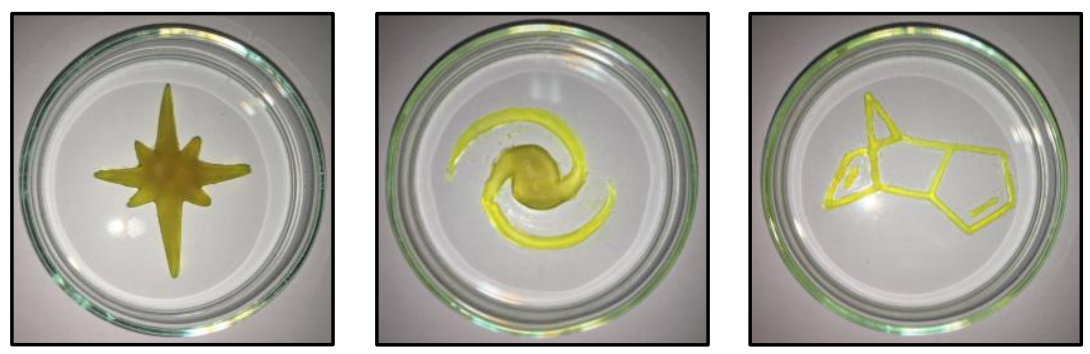

Pictures of more sophisticated patterns made of poly(dicyclopentadiene 12) in $80 \mathrm{~mm} \times 15 \mathrm{~mm}$ petri dishes.

- Thickness as a function of irradiation time

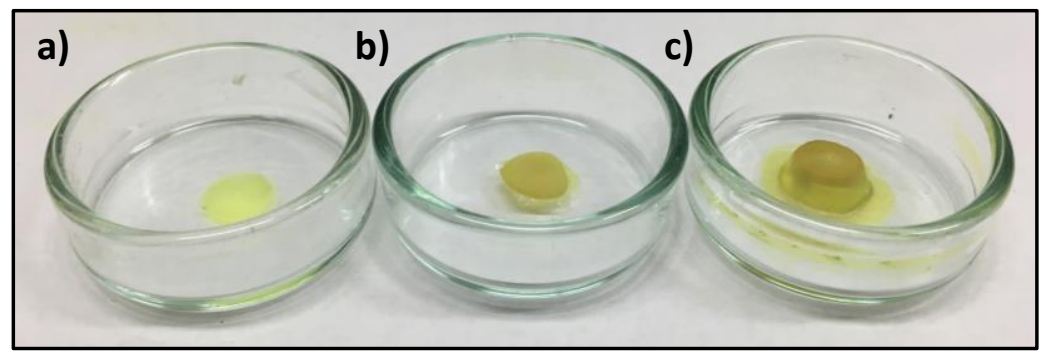

Picture of poly(dicyclopentadiene 12) obtained after 5 minutes (a), 15 minutes (b) and 60 minutes (c) of irradiation under visiblelight in $40 \mathrm{~mm} \times 12 \mathrm{~mm}$ petri dishes.

The thickness of the patterned polymers can be easily modulated by tuning the time of irradiation, as can be seen on the above picture displaying poly(dicyclopentadiene) patterns obtained after 5 minutes $(0.2 \mathrm{~mm}), 15$ minutes $(1.6-2.0 \mathrm{~mm})$ and 60 minutes $(3.8 \mathrm{~mm})$ of irradiation. All measures were made using an electronic digital micrometer). 


\section{Experimental Procedure and Results: Polymer Patterning using Blue Laser}

\section{General Procedure}

In a glovebox, an oven-dried $20 \mathrm{~mL}$ scintillation vial was charged with 2,4,6-triphenylpyrylium tetrafluoroborate TPPT (2.0 mg, $5 \mu \mathrm{mol}), \mathrm{CH}_{2} \mathrm{Cl}_{2}(3 \mathrm{~mL})$ and $\mathrm{RuCl}_{2}(\mathrm{CHPh})(\mathrm{IMes})_{2}(0.87 \mathrm{mg}, 1 \mu \mathrm{mol})$. Dicyclopentadiene $(1.32 \mathrm{~g}, 10 \mathrm{mmol})$ was then added and the solution was transferred into a BRAND $^{\circledR}$ petri dish (glass, $40 \mathrm{~mm} \times 12 \mathrm{~mm}$ ). Irradiation was carried out with a blue laser pointer $(450 \mathrm{~nm}, 200 \mathrm{~mW}$ ) through a magnifying glass. The support stand holding the laser was then moved either manually over 30-40 minutes or with an orbital shaker for 10 minutes (experimental setup 3). The petri dish was finally removed from the glovebox and unreacted monomer was thoroughly washed away with dichloromethane to afford the desired patterned poly(dicyclopentadiene).

\section{Results}
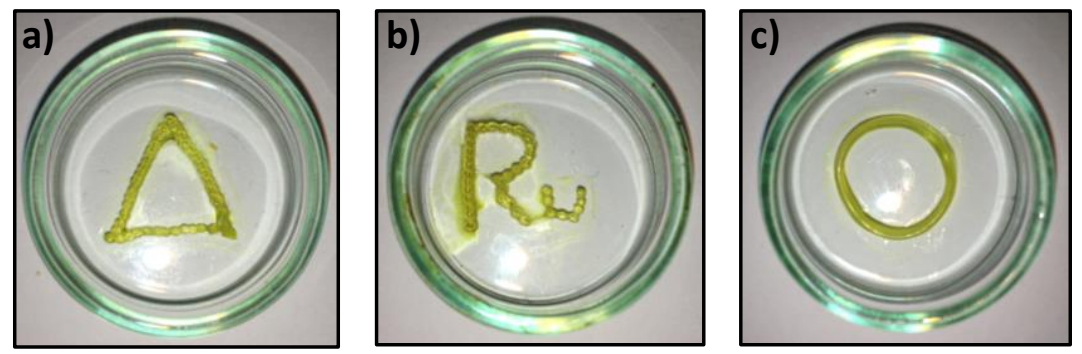

$(a, b)$ Pictures of poly(dicyclopentadiene 12) obtained after irradiation with a blue laser which was moved manually in $40 \mathrm{~mm} \times 12$ $\mathrm{mm}$ petri dishes. All dots required irradiation of around 20-25 seconds. The overall time of irradiation was around 30-40 minutes. (c) Picture of poly(dicyclopentadiene 12) obtained after irradiation for 10 minutes with a blue laser which was moved with an orbital shaker in a $40 \mathrm{~mm} \times 12 \mathrm{~mm}$ petri dish. 


\section{Experimental Procedures and Results: Photolithographic Applications on Silicon Wafers}

The strategy exploited for the photolithographic ring-opening metathesis polymerization of norbornadiene onto silicon wafers is similar to the strategy previously reported by Fourkas and coworkers. ${ }^{23}$ First, the functionalization of the silicon oxide layer of the silicon wafers with trichloro(5-norbornen-2-yl)silane was performed in order to attach a norbornene unit at the surface of the wafers. Our standard visible-light-promoted ring opening metathesis polymerization of norbornadiene was then performed on the silicon wafers which covalently bound to the growing polymer thanks to the norbornene unit present at the surface. Removal of the unreacted monomer finally afforded the desired patterned poly(norbornadiene) at the surface of the silicon wafers.

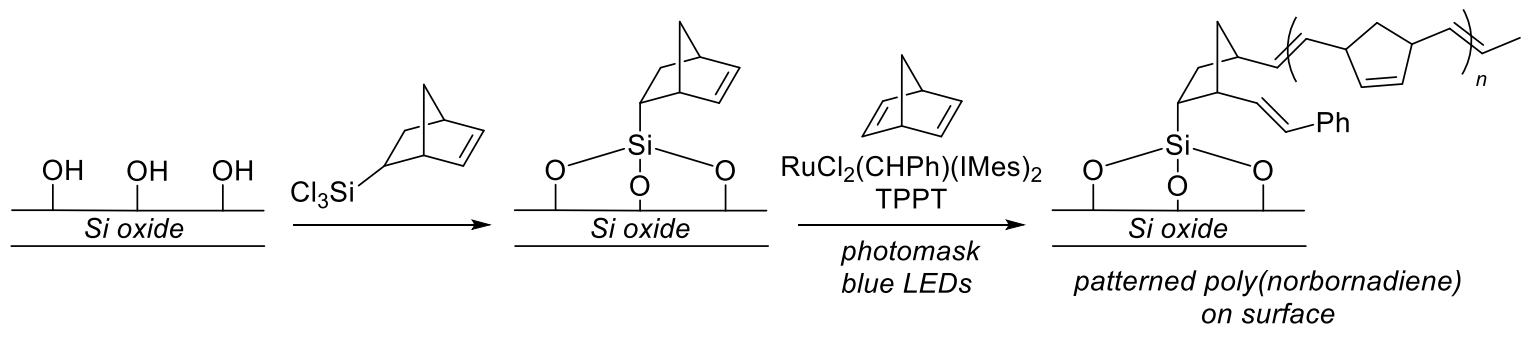

Functionalization of silicon wafers with trichloro(5-norbornen-2-yl)silane

Silicon wafers were cleaned by sonication in acetone (2 $\times 15$ minutes) and isopropanol ( $2 \times 15$ minutes), rinsed with isopropanol, dried under a stream of $\mathrm{N}_{2}$ and finally placed in an $\mathrm{O}_{2}$ plasma chamber under vacuum (100 mTorr) using a power of 50 watts for 2 minutes. The silicon wafers were immediately functionalized with trichloro(5-norbornen-2-yl)silane.

In a glovebox, a $60 \mathrm{~mL}$ screw-cap jar was charged with $20 \mathrm{~mL}$ of a solution of trichloro(5norbornen-2-yl)silane $(0.2 \mathrm{~mL})$ in anhydrous toluene $(20 \mathrm{~mL})$. Four to five $1 \mathrm{~cm} \times 1 \mathrm{~cm}$ silicon wafers with a native silicon oxide layer were added to the solution which was agitated overnight on an orbital shaker at room temperature. The silicon wafers were then thoroughly rinsed with anhydrous toluene, dried under a stream of $\mathrm{N}_{2}$ and stored in a glovebox prior to use. 
Angle contact measurements with a water drop were indicative of the successful grafting of the norbornene unit at the silicon wafer surface $\left(34^{\circ}\right.$ for a non-functionalized silicon wafer, $85^{\circ}$ for a norbornene-functionalized silicon wafer).

\section{Procedure for the photolithographic patterning of norbornene-functionalized silicon wafers}

In a glovebox, a norbornene-functionalized silicon wafer was placed on a microscope slide (22 $\mathrm{mm} \times 22 \mathrm{~mm}$, thickness of 0.13-0.17 mm). Four to five drops of a solution of norbornadiene (305 $\mu \mathrm{L}, \quad 3 \mathrm{mmol}), \mathrm{RuCl}_{2}(\mathrm{CHPh})(\mathrm{IMes})_{2}(1.3 \mathrm{mg}, 1.5 \mu \mathrm{mol})$ and 2,4,6-triphenylpyrylium tetrafluoroborate $(1.2 \mathrm{mg}, 3 \mu \mathrm{mol})$ in $\mathrm{CH}_{2} \mathrm{Cl}_{2}(1 \mathrm{~mL})$ were then added to cover the silicon wafer. A second microscope slide ( $22 \mathrm{~mm} \times 22 \mathrm{~mm}$, thickness of $0.13-0.17 \mathrm{~mm}$ ) was then quickly placed on top of the silicon wafer/solution. The mask was then placed on top of the second microscope slide and light was shined through the mask for 10 minutes. The silicon wafer was developed by pouring it twice into DCM for 1 minute before letting it dry under a steam of $\mathrm{N}_{2}$ to finally afford the desired patterned poly(norbornadiene) film.

\section{Results}
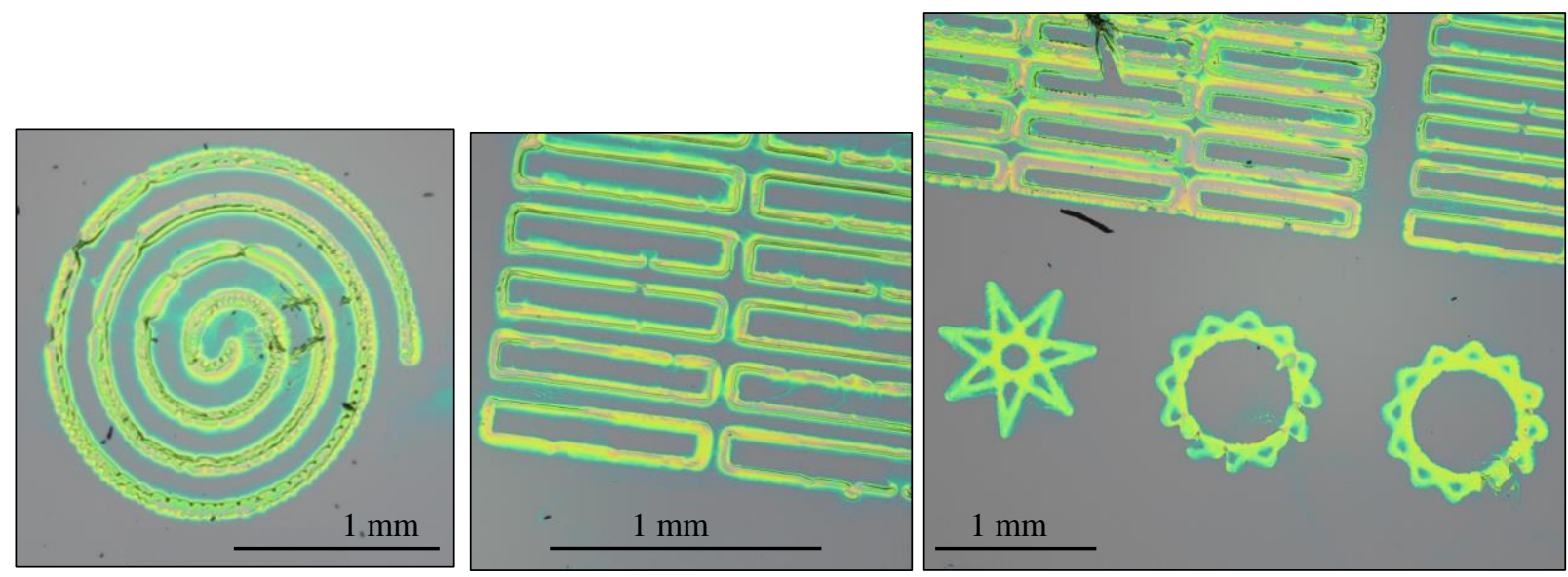

Micrographs of poly(norbornadiene 9) printed on norbornene-pre-functionalized silicon wafers. The width is $30-40$ microns. The height of the poly(norbornadiene) films was evaluated to 200-300 $\mathrm{nm}$ by AFM measurements. 
Supporting Information

\section{${ }^{1} \mathrm{H}$ and ${ }^{13} \mathrm{C}$ NMR spectra: \\ Previously Unreported Compounds}



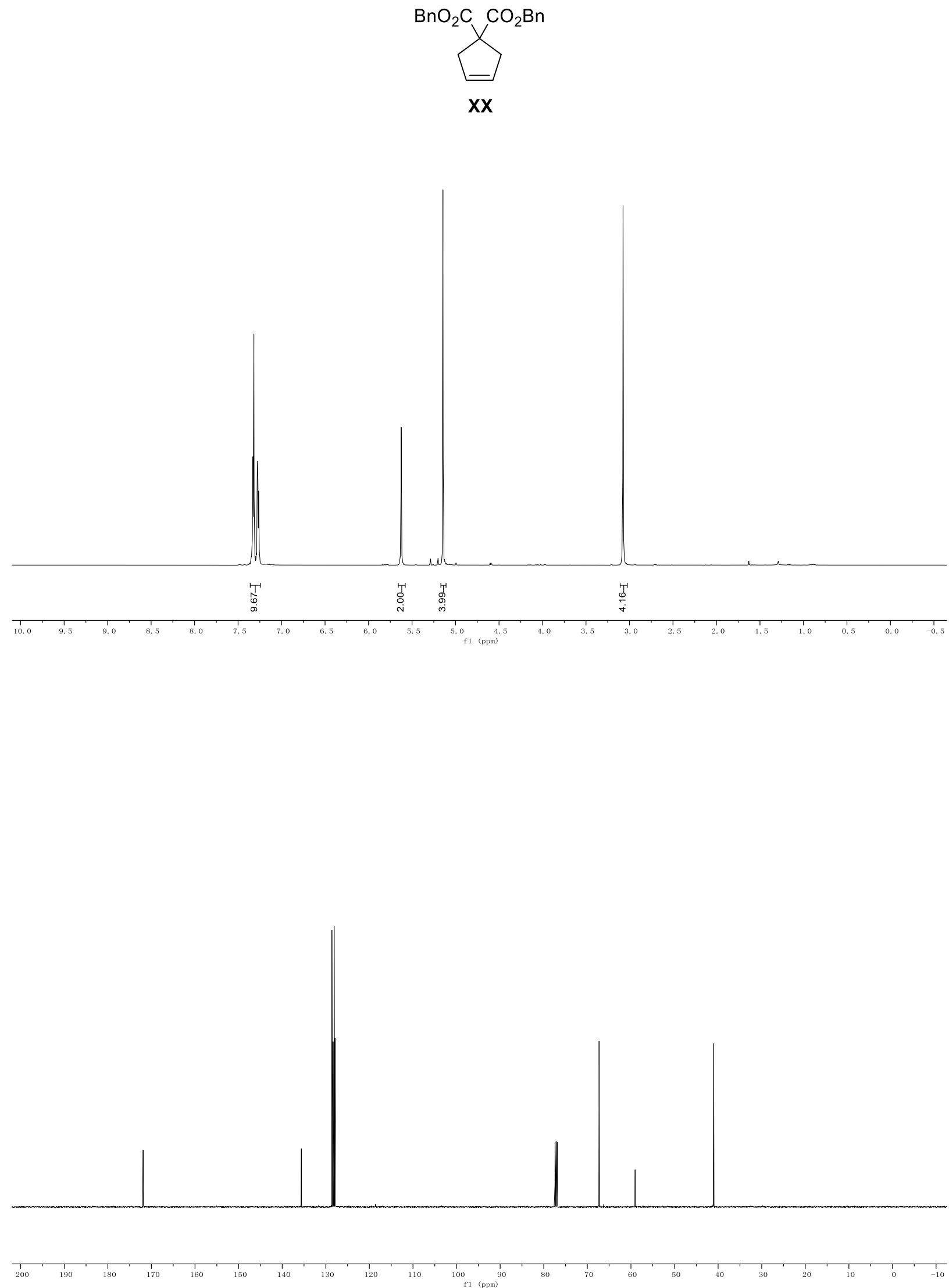

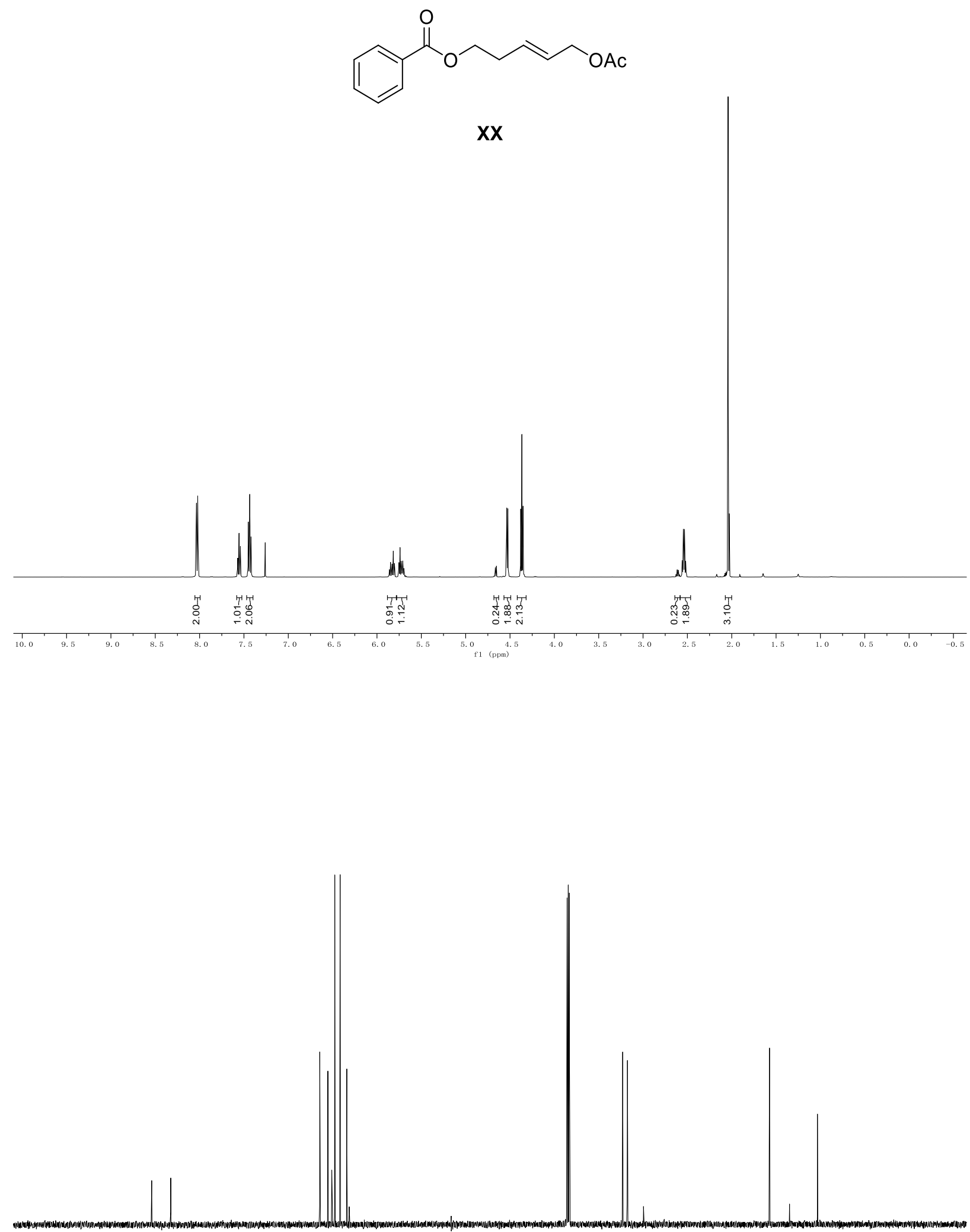

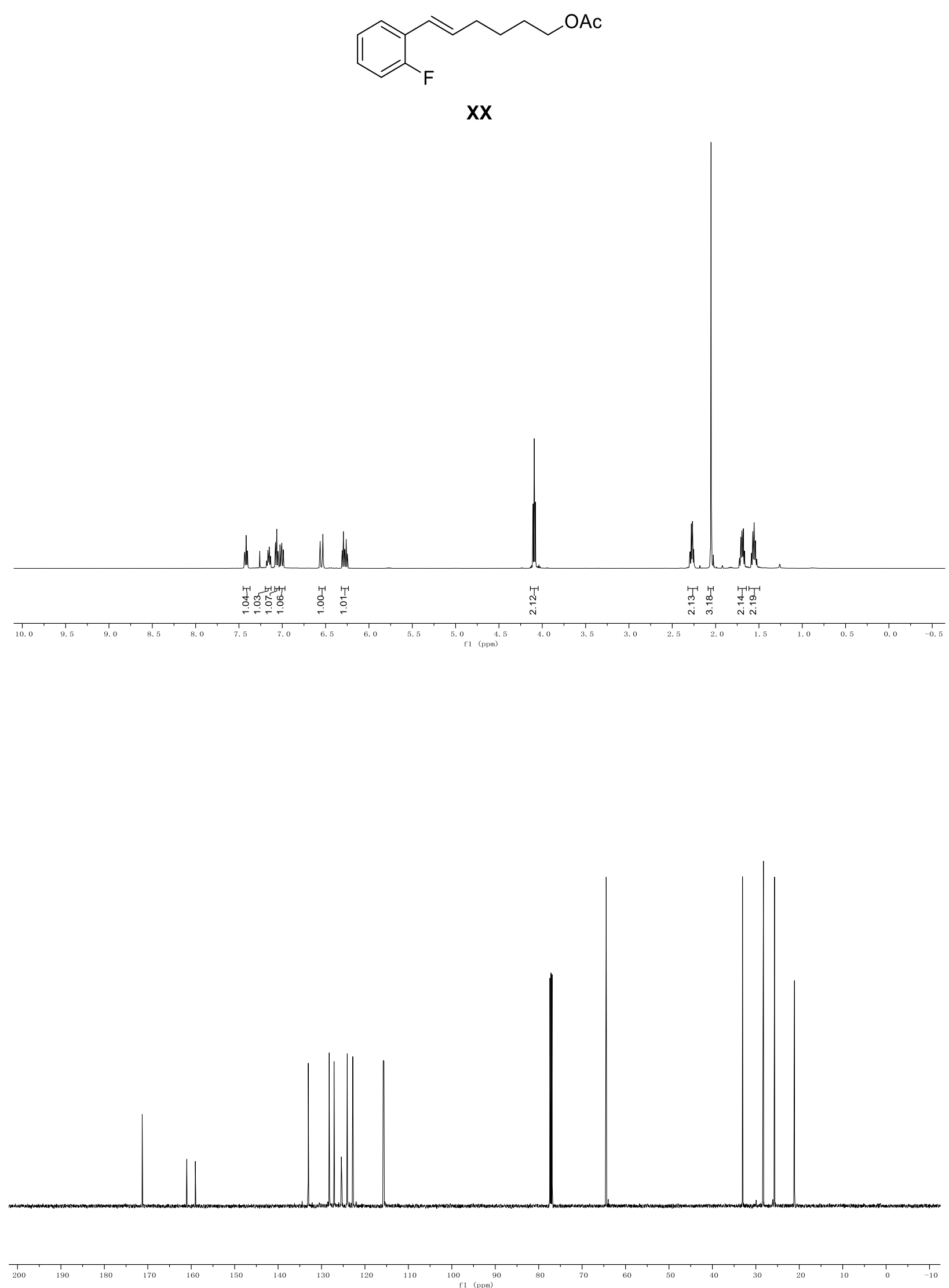

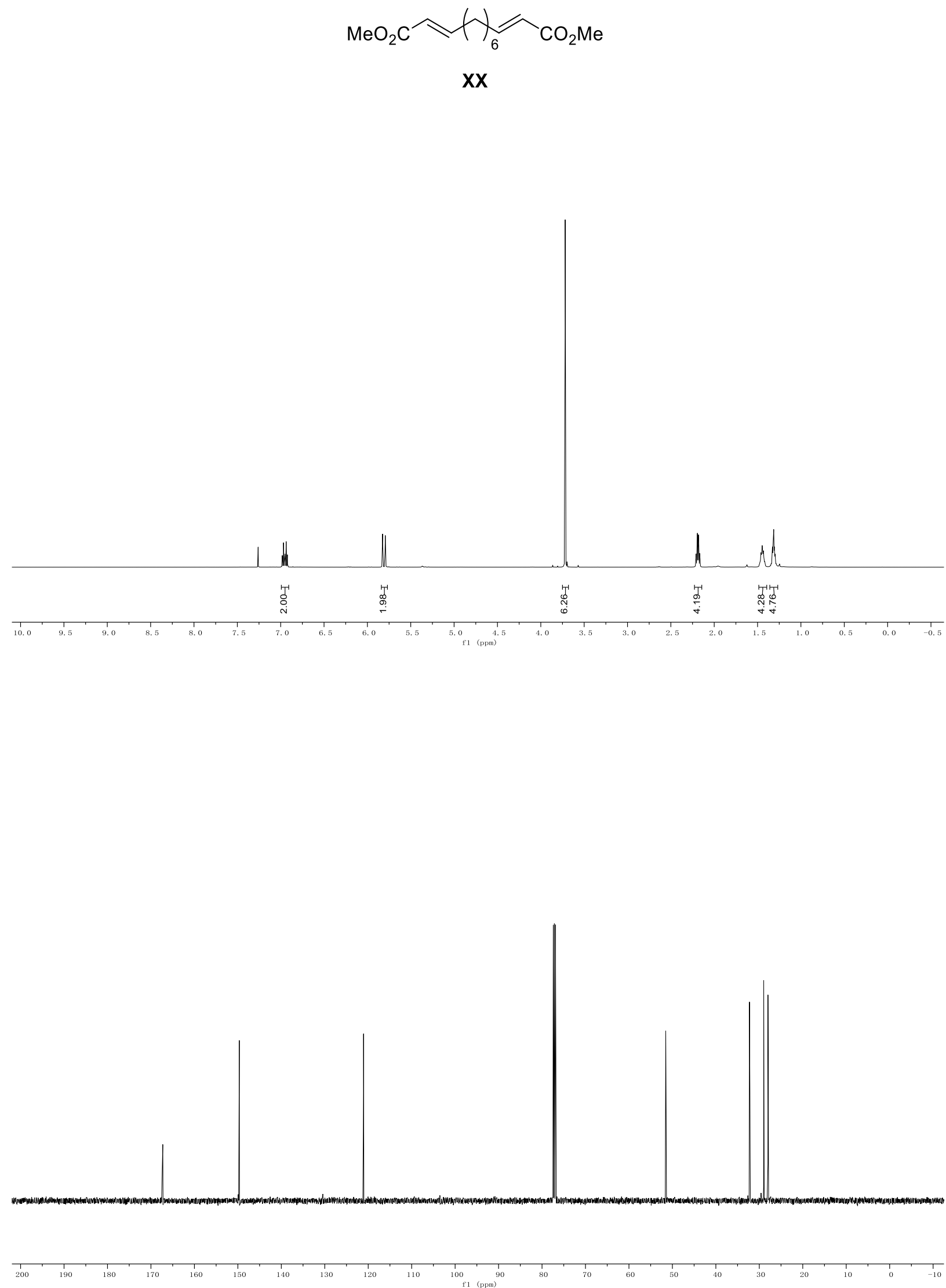


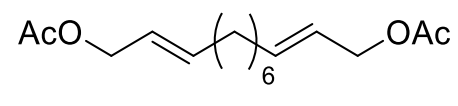

$\mathbf{X X}$
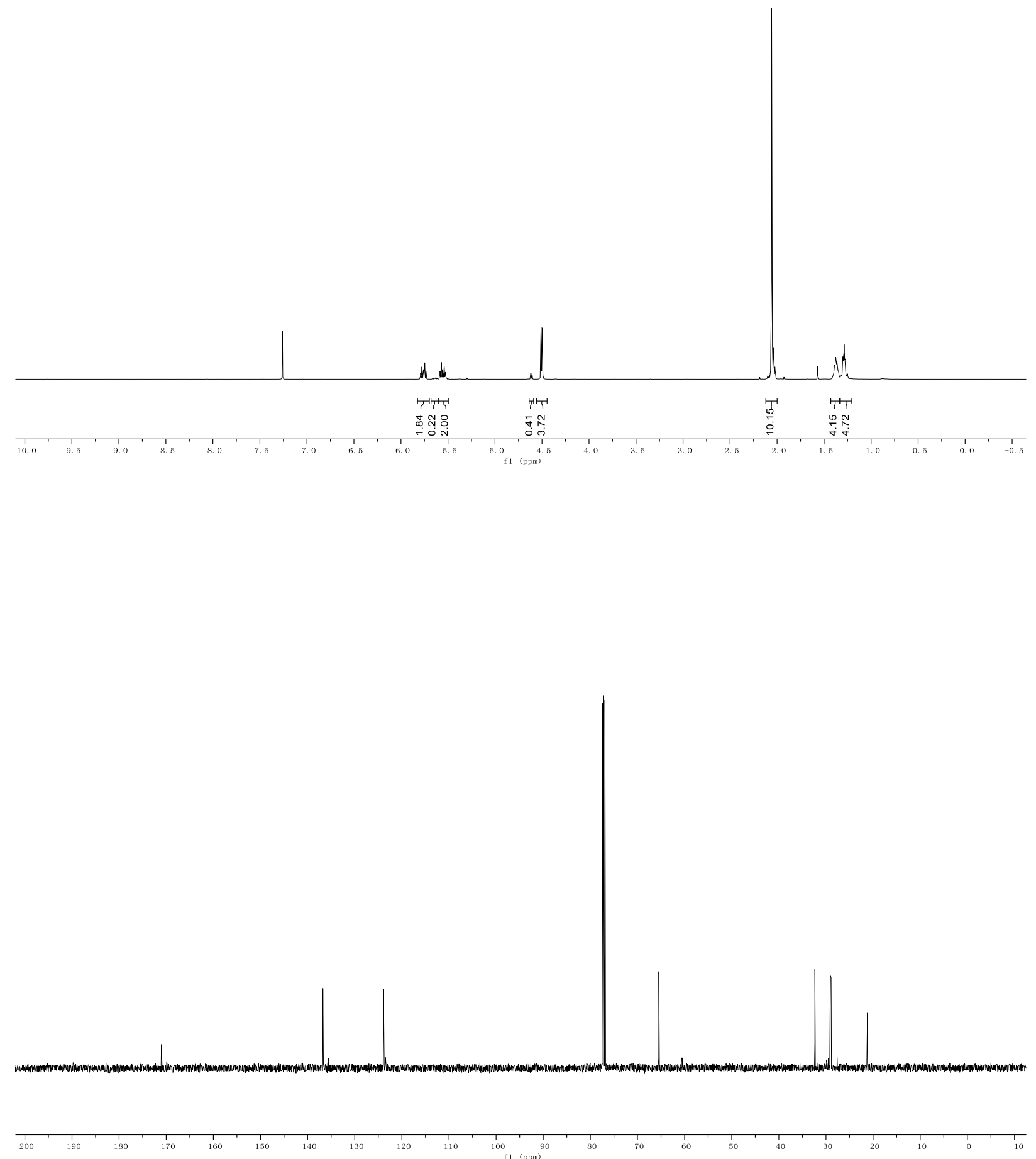


\section{References}

${ }^{1}$ Cunico, R. F. J. Org. Chem. 1971, 36, 929-932.

2 Jafarpour, L.; Nolan, S. P. Organometallics 2000, 19, 2055-2057.

${ }^{3}$ (a) Huang, J.; Stevens, E. D.; Nolan, S. P.; Petersen, J. L. J. Am. Chem. Soc. 1999, 121, 2674-2678. (b) Bantreil, X.; Nolan, S. P. Nat. Protoc. 2011, 6, 69-77.

4 (a) Sanford, M. S.; Love, J. A.; Grubbs, R. H. Organometallics 2001, 20, 5314-5318. (b) Conrad, J. C.; Yap, G. P. A.; Fogg, D. E. Organometallics 2003, 22, 1986-1988.

${ }^{5}$ Kotyk, M. W.; Gorelsky, S. I.; Conrad, J. C.; Carra, C.; Fogg, D. E. Organometallics 2009, 28, 5424-5431.

${ }^{6}$ Trnka, T. M.; Morgan, J. P.; Sanford, M. S.; Wilhelm, T. E.; Scholl, M.; Choi, T.-L.; Ding, S.; Day, M. W.; Grubbs, R. H. J. Am. Chem. Soc. 2003, 125, 2546-2558.

7 Tomar, P.; Vraun, T.; Kemnitz, E.; Chem. Commun., 2018, 54, 9753-9756.

${ }^{8}$ Ogawa, K. A.; Goetz, A. E.; Boydston, A. J. J. Am. Chem. Soc. 2015, 137, 1400-1403

${ }^{9}$ Yao, Q.; Zhang, Y. J. Am. Chem. Soc. 2004, 126, 74-75.

${ }^{10}$ Xi, Z.; Bazzi, H. S.; Gladysz, J. A. Org. Lett. 2011, 13, 6188-6191.

${ }^{11}$ Hongfa, C.; Tian, J.; Bazzi, H. S.; Bergbreiter, D. E. Org. Lett. 2007, 9, 3259-3261.

${ }^{12}$ Lipshutz, B. H.; Ghorai, S.; Abela, A. R.; Moser, R.; Nishikata, T.; Duplais, C.; Krasovskiy, A.; Gatson, R. D.; Gadwood, R. C. J. Org. Chem. 2011, 76, 4379-4391.

${ }^{13}$ Wu, G.-L.; Cao, S.-L.; Chen, J.; Chen, Z. Eur. J. Org. Chem. 2012, 6777-6784.

${ }^{14}$ Broggi, J.; Urbina-Blanco, C. A.; Clavier, H.; Leitgeb, A.; Slugovc, C.; Slawin, A. M. Z.; Nolan, S. P. Chem. Eur. J. 2010, 16, 9215-9225.

${ }^{15}$ Paz Muñoz, M.; de la Torre, M. C.; Sierra, M. A. Adv. Synth. Catal. 2010, 352, 2189-2194.

${ }^{16}$ Fürstner, A.; Ackermann, L.; Gabor, B.; Goddard, R.; Lehmann, C. W.; Mynott, R.; Stelzer, F.; Thiel, O. R. Chem. Eur. J. 2001, 7, 3236-3253.

${ }^{17}$ Wang, S.-Y.; Ji, S.-J.; Loh, T.-P. J. Am. Chem. Soc. 2007, 129, 276-277.

18 Bunnage, M. E.; Davies, S. G.; Goodwin, C. J.; Ichihara, O. Tetrahedron 1994, 50, 3975-3986.

${ }^{19}$ Busqué, F.; de March, P.; Figueredo, M.; Font, J. Tetrahedron 1995, 51, 1503-1508.

${ }^{20}$ Henderson, W. H.; Check, C. T.; Proust, N.; Stambuli, J. P. Org. Lett. 2010, 12, 824-827.

${ }^{21}$ Li, Z.; Zhang, Y.; Liu, Z.-Q. Org. Lett. 2012, 14, 74-77.

${ }^{22}$ Hata, T.; Hirone, N.; Sujaku, S.; Nakano, K.; Urabe, H. Org. Lett. 2008, 10, 5031-5033.

${ }^{23}$ Harris, R. F.; Ricci, M. J.; Farrer, R. A.; Praino, J.; Miller, S. J.; Saleh, B. E. A.; Teich, M. C.; Fourkas, J. T. Adv. Matter. 2005, 17, 39-42. 